\title{
Evaluation of the Sustainability of Integrated Hydrothermal Synthesis of Zeolites Obtained from Waste
}

\author{
Suzana F. Ferrarini,* Ariela M. Cardoso, Luisa Alban and Marçal J. R. Pires \\ Programa de Pós-Graduação em Engenharia e Tecnologia de Materiais, \\ Pontifícia Universidade Católica do Rio Grande do Sul, \\ Av. Ipiranga, 6681, 90619-900 Porto Alegre-RS, Brazil
}

\begin{abstract}
The high $\mathrm{Si}$ and $\mathrm{Al}$ contents in the amorphous phase of coal fly ash have been used for its conversion into zeolites. This process converts a toxic low-value by-product into a product used in a number of environmental applications, but has the disadvantage of introducing contaminants. Despite the large number of studies on the conversion of fly ash into zeolites, few report this drawback or discuss the efficiency of the proposed processes from a technical or ecological perspective. In this respect, the present study conducts a detailed assessment of two routes for integrated hydrothermal synthesis of zeolites 4A and Na-P1 obtained from coal fly ash. The processes are evaluated and compared in relation to the presence of undesirable metals and elements in the different steps of synthesis, as well as the feedstock and final product. Different performance parameters are presented and applied in the assessment of both processes and the most sustainable is recommended.
\end{abstract}

Keywords: coal fly ash, zeolite, contaminant, efficiency, sustainability

\section{Introduction}

Coal fly ash is a by-product widely produced in thermoelectric power plants during coal combustion..$^{1-3}$ This solid waste is considered harmful to the environment due to the presence of heavy metals and other potentially toxic substances..$^{4-7}$ Different applications are reported in the literature, including in the manufacturing of concrete, tiles and ceramic products and as a cement additive. ${ }^{2,7.8}$ However, this demand is often not enough to exhaust the amount of fly ash generated in the burning of vast quantities of coal worldwide, which can result in improper disposal. ${ }^{9}$ By contrast, an alternative application has attracted scientific interest for its use in the synthesis of zeolites due to the characteristics of the coal fly ash, which include high silicon and aluminum levels in the amorphous phase. These elements are the main constituents of the basic structure of zeolites, which are tetrahedral aluminosilicates with extensive industrial applications, especially in catalysis and as additives in detergents. ${ }^{6,10-15}$ Holler and Wirsching ${ }^{16}$ performed the first study on the conversion of coal fly ash into zeolites; since then, numerous publications and patents have been reported, ${ }^{1,6,13,14,17-19}$ including reviews. ${ }^{20,21}$ In this

*e-mail: suzana.ferrarini@gmail.com scenario, other wastes have also been studied as alternative sources of $\mathrm{Si}$ and $\mathrm{Al}$ to obtain zeolites. ${ }^{22,23}$

Conventional zeolite synthesis methods using coal fly ash involve hydrothermal dissolution of the $\mathrm{Si}$ and $\mathrm{Al}$ source in alkaline solution, as well as the nucleation and growth of crystals. ${ }^{12,15,17}$

Despite the large number of studies on fly ash conversion into zeolites, few report on the efficiency of the proposed processes from an economic or ecological perspective. Cardoso et al. ${ }^{13}$ optimized an integrated method of zeolite Na-P1 and 4A synthesis, referred to here as process $\mathrm{B}$. The authors analyzed two different routes based on a pioneering study by Hollman et al. ${ }^{18}$ The first step consists of extracting Si from fly ash, followed by synthesis of pure zeolite $4 \mathrm{~A}$ by combining the extract with a secondary source of aluminum. Solid waste from Si extraction may be suitable for conventional synthesis of low-purity zeolites, such as zeolite Na-P1. An alternative route (hereafter referred to as process $\mathrm{A}$ ) for the integrated process could begin with direct synthesis of Na-P1, resulting in an extract with higher $\mathrm{Si}$ levels that produces pure zeolite 4A when combined with a secondary source of Al. The efficiency of silicon and aluminum extraction from fly ash, effluent generation and the quality of the produced zeolites were assessed in processes A and B. However, it is 
important to underscore that, depending on the application of the produced zeolite, it is vital to evaluate the presence and mobility of contaminants in the initial ash.

The development of sustainable and environmentally friendly zeolite synthesis processes has attracted significant attention. ${ }^{24-27}$ The processes used to achieve so-called green zeolite synthesis must be simple and convenient, provide high yields and efficiency, as well as low waste, pollution and pressure. These criteria should be applied to any type of synthesis using either pure reagents or residues. ${ }^{6,25,28}$

As such, the present study aimed to conduct a detailed analysis of two integrated hydrothermal zeolite synthesis routes, using coal fly ash as the main feedstock. The processes are evaluated and compared with respect to the presence of undesirable metals and elements in the different steps of synthesis, as well as the feedstock and final product (zeolites). In order to achieve a more detailed comparison, different performance parameters (yield, recovery and atom efficiency) are used to assess both processes and contrast them with those reported in the literature. The most sustainable process is recommended.

\section{Experimental}

Material

Previously characterized (Table S1, in the Supplementary Information (SI) section) coal fly ash, obtained from unit B of the Presidente Médici Thermoelectric Power plant (Candiota, Brazil), was used for zeolite synthesis. This ash was chosen because it is generated in large quantities ( 1 million tons per year) in this plant and, only partially reused in clinker production. The samples were dried in an oven $\left(105^{\circ} \mathrm{C}, 2 \mathrm{~h}\right)$ and stored at ambient temperature away from the light until use. All chemicals were analytical grade. All the solutions and samples were prepared using high purity deionized water (> 18.2 M $\Omega \mathrm{cm}$, Milli-Q system, Millipore).

\section{Zeolite synthesis methodology - process $\mathrm{A}$}

This integrated synthesis process followed the procedure adapted by Cardoso et al. ${ }^{13}$ and is shown in Figure 1a. Process A consists of two steps; initially, the fly ash $(15 \mathrm{~g})$ was activated with $90 \mathrm{~mL}$ of $3.0 \mathrm{~mol} \mathrm{~L}^{-1}$ $\mathrm{NaOH}$ solution (L/S ratio $6 \mathrm{~L} \mathrm{~kg}^{-1}$ ) in a closed reactor $\left(100{ }^{\circ} \mathrm{C}, 24 \mathrm{~h}\right)$. The first obtained zeolite, Na-P1 (IIA), was separated by filtration (glass fiber filter, $0.22 \mu \mathrm{m}$ ), washed until pH 10 and dried $\left(105{ }^{\circ} \mathrm{C}, 2 \mathrm{~h}\right)$. The extract (IA) from this first step was quantified for $\mathrm{Si}$ and $\mathrm{Al}$ in order to determine an accurate molar ratio to obtain a high-quality product in the second step of the process (zeolite 4A,
$\mathrm{Si} / \mathrm{Al}$ ratio $=1.0)$. Concentrations of these two elements were measured by flame atomic absorption spectroscopy (FAAS, Varian SpectrAA 55). In order to evaluate the quality of the extract produced in the first step and the final effluent (IIIA) generated, both were characterized in terms of the presence of additional contaminants using inductively coupled plasma mass spectrometry (ICP-MS, Agilent 7770X).

Aluminum powder (aluminum fine powder for synthesis, $>99 \%$, Merck), previously dissolved in alkaline solution (3.0 mol L-1 $\mathrm{NaOH}$ ) at the appropriate concentration, was used to adjust the $\mathrm{Si} / \mathrm{Al}$ ratio. The resulting solution was transferred to a closed reactor, manually shaken and then heated in an oven at $90{ }^{\circ} \mathrm{C}$ for $1.5 \mathrm{~h}$, followed by another $2.5 \mathrm{~h}$ at $95{ }^{\circ} \mathrm{C} .{ }^{13,29}$ The obtained zeolite (4A, IVA) was filtered, washed until $\mathrm{pH} 10$ and dried $\left(105^{\circ} \mathrm{C}, 2 \mathrm{~h}\right)$.

Since fly ash is a heterogeneous material that contains a wide variety of potentially toxic elements, ${ }^{5,30,31} 15$ synthesis tests were performed under the same conditions. The amounts of extracted $\mathrm{Si}$ and $\mathrm{Al}$ and possible contaminants were individually characterized in the products and effluents. Zeolites Na-P1 and 4A obtained in the fifteen tests were evaluated in terms of morphology, chemical composition and cation exchange capacity (CEC), with similar results among the replicates. As such, the fifteen samples were combined for each type of zeolite and the resulting two samples were characterized in detail (X-ray fluorescence (XRF) and X-ray diffraction (XRD)), applying acid decomposition to identify the component elements ( $\mathrm{Si}$, $\mathrm{Al}$ and $\mathrm{Na}$ ) and contaminants present in both materials by FAAS and ICP-MS.

\section{Zeolite synthesis methodology - process B}

The second synthesis method, originally proposed by Hollman et al.,$^{18}$ and adapted by Cardoso et al. ${ }^{13}$ for the integrated synthesis of zeolites 4A (first step) and Na-P1 (second step), is shown in Figure 1b. $30 \mathrm{~g}$ of coal fly ash were added to $300 \mathrm{~mL}$ of $2.0 \mathrm{~mol} \mathrm{~L}-1 \mathrm{NaOH}(\mathrm{L} / \mathrm{S}$ ratio $10 \mathrm{~L} \mathrm{~kg}^{-1}$ ) in an open reactor (water bath at $85^{\circ} \mathrm{C}$, under magnetic stirring, for $2 \mathrm{~h}$ ). After cooling, the mixture was filtered (glass fiber filter, $0.22 \mu \mathrm{m}$ ) and the solid residue (residual ash, IIB) dried $\left(105^{\circ} \mathrm{C}, 2 \mathrm{~h}\right.$ ) and stored for future testing. $\mathrm{Si}$ and $\mathrm{Al}$ were quantified in the resulting extract (IB) to determine the molar ratio. The secondary aluminum source was $\mathrm{NaAlO}_{2}(99 \%$, Merck), solubilized in a $2.0 \mathrm{~mol} \mathrm{~L}^{-1} \mathrm{NaOH}$ solution and added to the extract. The resulting mixture was transferred to a closed reactor and maintained at $90{ }^{\circ} \mathrm{C}$ for $1.5 \mathrm{~h}$, followed by a further $2.5 \mathrm{~h}$ at $95^{\circ} \mathrm{C}$. After cooling, the obtained zeolitic material (zeolite 4A, IVB) was filtered, washed and dried in line with 
(a)
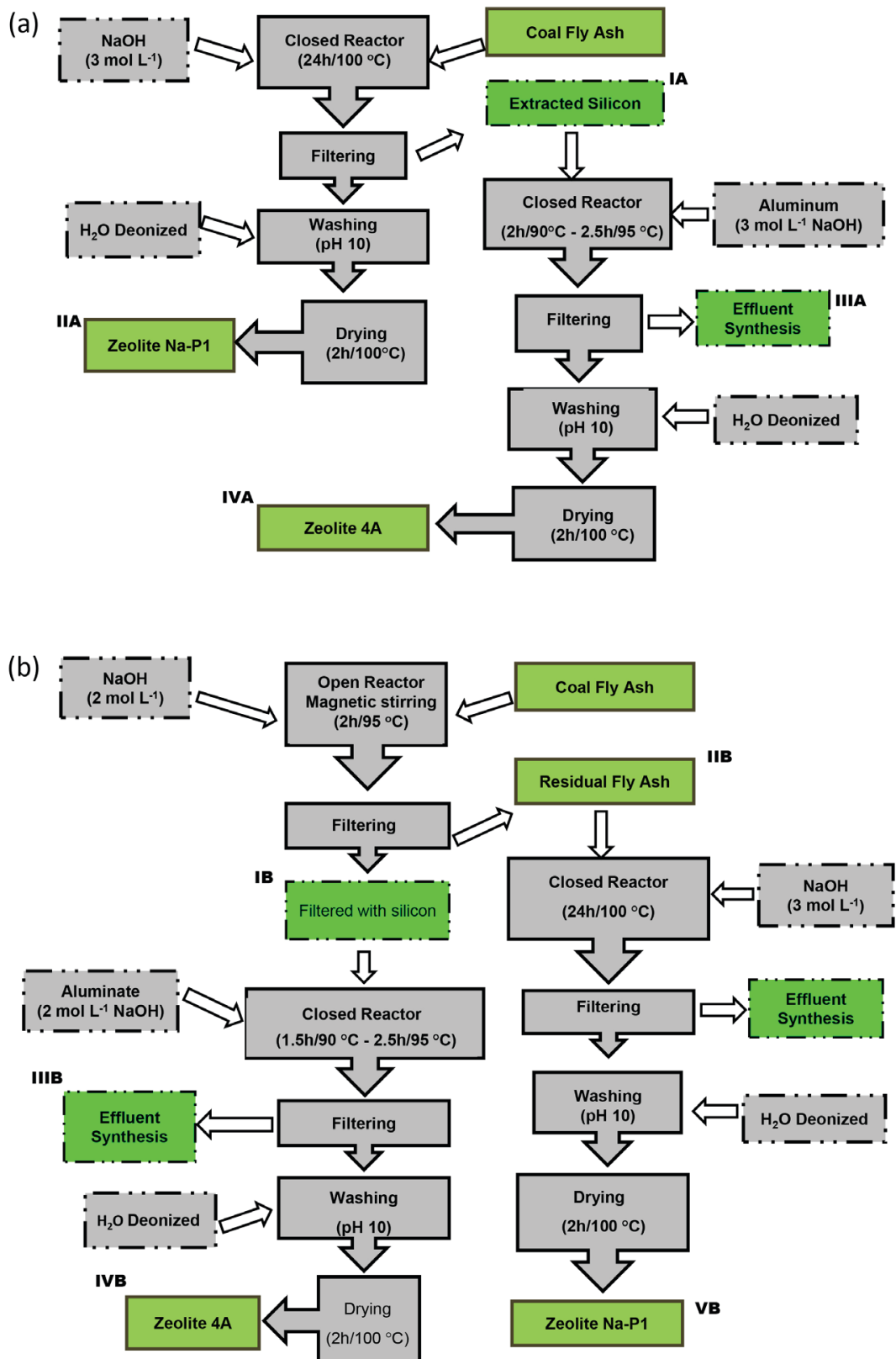

Figure 1. Flow diagrams of integrated zeolite synthesis via (a) process A and (b) process B. Rectangles depict material input and output in the solid (solid line) and aqueous (dashed line) steps, while rectangles with arrows indicate operations. Roman numerals indicate outputs for which the chemical composition was measured.

the previously described process. The resulting effluents were characterized in relation to possible contaminants. The residual ash generated in the first step was characterized and submitted to zeolitization (closed reactor, $3.0 \mathrm{~mol} \mathrm{~L}^{-1}$ $\mathrm{NaOH}, 100{ }^{\circ} \mathrm{C}, 24 \mathrm{~h}$ ), yielding a second zeolitic product containing Na-P1 (VB), which was filtered, washed and dried as described above. In light of the good reproducibility observed in process A, only three replicates were performed for process B. After preliminary characterization (scanning electron microscopy-energy dispersive $\mathrm{x}$-ray spectroscopy (SEM-EDS), CEC), the zeolites obtained in each step were combined, homogenized and characterized in detail as described in process $\mathrm{A}$.

\section{Characterization of solid products, extracts and effluents}

In order to determine the initial amount of the studied elements, the solid samples resulting from process $A$ (zeolites Na-P1 and 4A) and process B (zeolites 4A and $\mathrm{Na}-\mathrm{P} 1$; residual ash) were submitted to acid decomposition in Teflon ${ }^{\circledR}$ bombs, according to the methodology adapted by Ferrarini et al. ${ }^{5}$ Thirty elements were quantified using 
the ICP-MS and FAAS techniques. The solid samples were characterized by X-ray fluorescence (Shimadzu XRF-1800) for the presence of 17 major elements, expressed as oxides. To prevent calibration problems with the XRF technique and guarantee accurate results, samples of certified reference materials (CRMs) of both ash and zeolites were studied under the same analysis conditions and the obtained results were considered satisfactory for elements with certified values.

Morphological characterization was carried out by scanning electron microscopy (SEM, Philips XL 30).

The mineral composition of solid product samples was analyzed by X-ray diffraction (Shimadzu XRD-7000) using theta-theta geometry, with $\mathrm{Cu} \mathrm{K} \alpha$ radiation generated at $40 \mathrm{kV}$ and $30 \mathrm{~mA}, 0.02^{\circ}$ scan step and angular $2 \theta$ range from 5 to $80^{\circ}$. The crystalline phases in the samples were identified using the Joint Committee on Powder Diffraction Standards (JCPDS) file for inorganic compounds.

$\mathrm{Si}$ and $\mathrm{Al}$ exhibit different solubility in association with amorphous or crystalline phases in fly ash, whereby dissolution of both elements occurs more easily in the amorphous phase, thus favoring zeolite production. ${ }^{6}$ As such, recovery values for the elements were calculated by subtracting the $\mathrm{Si}$ and $\mathrm{Al}$ levels associated with the crystalline phases (quartz and mullite), determined by XRD, from the levels present in the amorphous phase (see Table S1), estimated based on XRF data.

The cation exchange capacity of the zeolites was tested by placing zeolite Na-P1 in contact with $0.1 \mathrm{~mol} \mathrm{~L}^{-1}$ $\mathrm{NH}_{4} \mathrm{Cl}$ solution ${ }^{32}$ and zeolite $4 \mathrm{~A}$ with a $0.1 \mathrm{~mol} \mathrm{~L}^{-1} \mathrm{CaCl}_{2}$ solution. ${ }^{13}$ The mixture was stirred using a device that rotates the extraction vessel end-over-end (Marconi MA 160), centrifuged and the extract separated for ion quantification. $\mathrm{Na}$ and $\mathrm{Ca}$ were quantified in zeolite $4 \mathrm{~A}$ by FAAS, and $\mathrm{NH}_{4}$ quantification was performed for zeolite Na-P1 in a UVVis spectrophotometer (HP 8456). The CEC values of the produced zeolites were used to estimate their purity (see item "Calculation of zeolitic product purity" of the SI section).

Item "Calculation of process yields and efficiencies" of the SI section shows the calculations for the yield, recovery and efficiency of zeolite extraction and synthesis as well as effluent generation, used to compare the sustainability of the processes studied.

\section{Results and Discussion}

\section{Synthesis using process $\mathrm{A}$}

\section{Extraction step and formation of the low-grade zeolite}

The first step in this process consists of extracting $\mathrm{Si}$ and $\mathrm{Al}$ from the coal fly ash into the alkaline solution and the simultaneous formation of zeolite Na-P1 in the solid product. This stage is decisive in both the quantity and quality of the product formed in the second step (zeolite 4A). Table 1 shows the composition of the extracts and characteristics of the zeolitic products obtained in the first step of synthesis.

The mean volume of the obtained extract $(74 \pm 6 \mathrm{~mL})$ indicates a significant decline (18\%) in relation to the initial volume $(90 \mathrm{~mL})$, likely because the reactor was not hermetically sealed. In all the tests performed, more silicon was extracted (mean $1.43 \pm 0.17 \mathrm{~g}$ ) than aluminum $(0.02 \pm 0.01 \mathrm{~g})$. One of the reasons for this significant difference $(80 \times)$ is related to the composition of the fly ash used, which contains approximately three times more Si than Al (Table S1). Several authors have reported similar behavior in the alkaline extraction of different types of fly ash. ${ }^{5,13,33,34}$ For example, Moreno et al..$^{34}$ studied the zeolitization process in 23 different types of fly ash and attributed the fact primarily to the varying solubility of the crystalline (quartz, mullite, etc.) and amorphous phases (glass) present. These aspects explain the different recovery values obtained for $\mathrm{Si}\left(\mathrm{R}_{\mathrm{si}} 31 \pm 4 \%\right)$ and $\mathrm{Al}\left(\mathrm{R}_{\mathrm{Al}} 1.0 \pm 0.7 \%\right)$ in the extracts when compared to the total amount of the elements in the fly ash from Candiota. Slightly higher recovery values $\left(\mathrm{R}_{\mathrm{Si}} \mathrm{Si} 38 \pm 5 \%\right.$ and $\left.\mathrm{R}_{\mathrm{Al}} \mathrm{Al} 1.3 \pm 0.9 \%\right)$ were observed when considering only the easily soluble amorphous phases containing these elements in the ash (Table S1). These results are comparable to those reported in other studies ${ }^{13,33}$ and can be considered satisfactory with respect to $\mathrm{Si}$. In regard to the reproducibility of the extraction step, relatively low coefficients of variation (12\%) were recorded for $\mathrm{Si}$, with greater variability observed for $\mathrm{Al}(73 \%)$. These variations indicate a greater contribution by analytical uncertainties in determining these elements, particularly for $\mathrm{Al}$, since lower concentrations were obtained than in the extraction process.

The results for the solid product $(\mathrm{mP})$ showed a mean mass of $13.2 \pm 0.4 \mathrm{~g}$, corresponding to $0.88 \pm 0.03 \mathrm{~g}$ of product per $\mathrm{g}$ of ash. Considering zeolite $\mathrm{Na}-\mathrm{P} 1$ as the main phase present in the solid (item "Zeolite characterization") and CEC $\left(3.0 \pm 0.6\right.$ meq $\left.\mathrm{NH}_{4}{ }^{+} \mathrm{g}^{-1}\right)$ as the parameter to estimate its content, ${ }^{13,19}$ it was estimated that mean purity of $65 \pm 12 \%$ indicates the production of $8.6 \pm 1.5 \mathrm{~g}$ of zeolite $\mathrm{Na}-\mathrm{P} 1$ per $\mathrm{g}$ of ash ( $0.57 \mathrm{~g}$ of zeolite per $\mathrm{g}$ of fly ash). These results are higher than those obtained by Cardoso et al., ${ }^{13}$ who reported purity of $54 \pm 4 \%$ under similar conditions. It is important to note that most authors do not report yield values in relation to the zeolite content in the obtained products. For example, Moreno et al..$^{33}$ found maximum yields for zeolite Na-P1 of $1.23 \mathrm{~g}$ of product per $\mathrm{g}$ of ash, under harsher reaction conditions $\left(120^{\circ} \mathrm{C}, 9 \mathrm{~h}, \mathrm{~L} / \mathrm{S}\right.$ ratio 3.0 in $\left.3.0 \mathrm{~mol} \mathrm{~L}^{-1} \mathrm{NaOH}\right)$. However, when zeolite content in the 
Table 1. Characterization of the solid (zeolitic product, Na-P1) and extract resulting from the first step of process A

\begin{tabular}{|c|c|c|c|c|c|c|c|c|c|c|c|c|}
\hline \multirow{3}{*}{ Test } & \multirow{3}{*}{$\begin{array}{c}\text { Fly ash } \\
\begin{array}{c}\mathrm{m}_{\mathrm{FA}} / \\
\mathrm{g}\end{array}\end{array}$} & \multicolumn{7}{|c|}{ Extract (IA) } & \multicolumn{4}{|c|}{ Zeolitic product (IIA, NaP1) } \\
\hline & & \multirow{2}{*}{$\begin{array}{c}\text { Volume } \\
\mathrm{V}_{\mathrm{Ex}} / \\
\mathrm{mL}\end{array}$} & \multicolumn{2}{|c|}{ Element mass } & \multicolumn{2}{|c|}{ Si recovery } & \multicolumn{2}{|c|}{ Al recovery } & \multirow{2}{*}{$\begin{array}{c}\mathrm{mP} / \\
\mathrm{g}\end{array}$} & \multirow{2}{*}{$\begin{array}{c}\mathrm{mZ} / \\
\mathrm{g}\end{array}$} & \multirow{2}{*}{$\begin{array}{c}\mathrm{CEC} \\
\begin{array}{c}\mathrm{NH}_{4}^{+} / \\
\left(\mathrm{meq} \mathrm{g}^{-1}\right)\end{array}\end{array}$} & \multirow{2}{*}{$\begin{array}{c}\text { Purity } \\
\text { PZ / } \\
\%\end{array}$} \\
\hline & & & $\begin{array}{c}\mathrm{m}_{\mathrm{Si} \text { Ext. }} / \\
\mathrm{g}\end{array}$ & $\begin{array}{c}\mathrm{m}_{\mathrm{Al} \mathrm{Ext.}} / \\
\mathrm{g}\end{array}$ & $\begin{array}{c}\text { Total / } \\
\% \\
\end{array}$ & $\begin{array}{c}\text { Amorphous / } \\
\%\end{array}$ & $\begin{array}{c}\text { Total / } \\
\%\end{array}$ & $\begin{array}{c}\text { Amorphous / } \\
\%\end{array}$ & & & & \\
\hline 1 & 15.04 & 73 & 1.66 & 0.02 & 35 & 44 & 1.1 & 1.4 & 12.6 & 6.9 & 2.5 & 54 \\
\hline 2 & 15.00 & 72 & 1.68 & 0.01 & 36 & 45 & 0.5 & 0.7 & 13.6 & 7.7 & 2.6 & 57 \\
\hline 3 & 15.01 & 80 & 1.53 & 0.01 & 33 & 40 & 0.7 & 0.8 & 13.3 & 6.3 & 2.2 & 48 \\
\hline 4 & 15.09 & 72 & 1.52 & 0.01 & 32 & 40 & 0.5 & 0.7 & 13.0 & 11.0 & 3.9 & 85 \\
\hline 5 & 15.05 & 76 & 1.12 & 0.05 & 24 & 30 & 2.7 & 3.4 & 12.4 & 7.8 & 2.9 & 63 \\
\hline 6 & 15.00 & 77 & 1.46 & 0.01 & 31 & 39 & 0.7 & 0.9 & 13.0 & 8.2 & 2.9 & 63 \\
\hline 7 & 15.00 & 70 & 1.30 & 0.02 & 28 & 35 & 0.9 & 1.1 & 13.2 & 9.5 & 3.3 & 72 \\
\hline 8 & 15.03 & 75 & 1.46 & 0.02 & 31 & 39 & 0.9 & 1.2 & 13.0 & 12.4 & 4.4 & 96 \\
\hline 9 & 15.01 & 82 & 1.45 & 0.01 & 31 & 38 & 0.5 & 0.6 & 13.2 & 8.6 & 3.0 & 65 \\
\hline 10 & 15.00 & 74 & 1.30 & 0.01 & 28 & 35 & 0.7 & 0.9 & 13.6 & 9.5 & 3.2 & 70 \\
\hline 11 & 14.97 & 59 & 1.26 & 0.01 & 27 & 34 & 0.3 & 0.4 & 13.7 & 8.6 & 2.9 & 63 \\
\hline 12 & 14.99 & 65 & 1.31 & 0.00 & 28 & 35 & 0.2 & 0.3 & 13.5 & 7.9 & 2.7 & 59 \\
\hline 13 & 15.03 & 80 & 1.61 & 0.03 & 35 & 43 & 1.5 & 1.9 & 13.6 & 7.7 & 2.6 & 57 \\
\hline 14 & 15.08 & 74 & 1.20 & 0.03 & 26 & 32 & 1.5 & 1.9 & 13.0 & 7.9 & 2.8 & 61 \\
\hline 15 & 15.06 & 80 & 1.60 & 0.04 & 34 & 42 & 2.5 & 3.1 & 13.8 & 8.7 & 2.9 & 63 \\
\hline Average & 15.02 & 74 & 1.43 & 0.02 & 31 & 38 & 1.0 & 1.3 & 13.2 & 8.6 & 3.0 & 65 \\
\hline SD & 0.03 & 6 & 0.17 & 0.01 & 4 & 5 & 0.7 & 0.9 & 0.4 & 1.5 & 0.6 & 12 \\
\hline RSD / \% & 0.2 & 8 & 12 & 73 & 12 & 12 & 73 & 73 & 3 & 18 & 19 & 19 \\
\hline
\end{tabular}

$\mathrm{m}_{\mathrm{FA}}$ : initial ash mass; $\mathrm{V}_{\mathrm{Ex}}$ : extract volume; $\mathrm{m}_{\mathrm{Si} \text { Ext }}$ and $\mathrm{m}_{\mathrm{Al} \text { Ext }}$ : mass of $\mathrm{Si}$ and $\mathrm{Al}$ extracted; $\mathrm{Si}$ and $\mathrm{Al}$ recoveries (total $/ \%$ ): calculated based on the extracted mass of these elements in relation to their total contents in the ash (presented in the sequence); Si and Al recovery (amorphous / \%): calculated based on the extracted mass of these elements in relation to their contents in the amorphous phase of the ash (Table S1); mP: mass of the product; mZ: zeolite mass in the product; CEC: cation exchange capacity; PZ: semi-quantitative zeolite content in the products; SD: standard deviation; RSD: relative standard deviation.

product (49\%) was taken into account, yield fell to $0.6 \mathrm{~g}$ of zeolite per $\mathrm{g}$ of fly ash, similar to that obtained in the present study. These values corroborate the other obtained results, indicating good yield and atom efficiency for the first step of the process. Despite this limitation, these indicators are important in assessing the sustainability of these processes in terms of green chemistry principle ${ }^{35}$ and will be discussed in detail in the item "Zeolite contamination between the two synthesis processes".

Table 2 presents the results of the chemical composition of the 15 extracts obtained in process A. High concentrations ( $>5 \mathrm{mg} \mathrm{L}^{-1}$ ) of $\mathrm{Fe}, \mathrm{V}$ and $\mathrm{Rb}$ were recorded, whereas levels $<0.1 \mathrm{mg} \mathrm{L}^{-1}$ were observed for $\mathrm{Cr}, \mathrm{Sr}, \mathrm{Cu}, \mathrm{Mn}$ and $\mathrm{Ag}$. Concentrations of most of the elements exhibited coefficients of variation $<50 \%$, considering the low levels evaluated. These results confirm good reproducibility for this step of the process, making it relevant for industrial applications.

The last column of this table shows the recovery percentages of the elements considering their content in the coal fly ash (Table S1). Higher recovery values were observed for As, $\mathrm{V}, \mathrm{Ag}$ and $\mathrm{Rb}(>34 \%)$, greater than $\mathrm{Si}$ itself (30\%). By contrast, recovery values for $\mathrm{Cr}, \mathrm{Sr}, \mathrm{Mg}, \mathrm{Fe}$ and $\mathrm{Mn}(<0.9 \%)$ were lower than those recorded for $\mathrm{Al}(1 \%)$. These results indicate that the use of this extract to produce zeolite results in contamination by As and Ag, elements that exhibit toxicity. ${ }^{36,37}$ However, it is important to underscore that, in order to pose a real threat, these elements would have to be transferred to the final product (zeolite 4A) and display significant mobility at the time of their use.

\section{Synthesis of the high-purity zeolite (second step)}

Table 3 shows the results of zeolite 4A synthesis using the extracts obtained in the first step. As previously mentioned, the different $\mathrm{Si}$ and $\mathrm{Al}$ levels in the extracts make it important to establish an accurate molar ratio ( $\mathrm{Si} / \mathrm{Al}$ ratio $=1)$, using aluminum powder solubilized in alkaline solution $\left(3.0 \mathrm{~mol} \mathrm{~L}^{-1}\right)$. In this step, the mean mass of the obtained solid product $(\mathrm{mP})$ was $7.0 \pm 0.9 \mathrm{~g}$, corresponding to $0.47 \pm 0.06 \mathrm{~g}$ of product per $\mathrm{g}$ of ash. Considering zeolite $4 \mathrm{~A}$ as the only phase present, 
Table 2. Concentration of the elements in the 15 extraction tests in the first step of process A

\begin{tabular}{|c|c|c|c|c|c|c|c|c|c|c|c|c|c|c|c|c|c|c|}
\hline \multirow{2}{*}{ Element } & \multicolumn{15}{|c|}{ Test - concentration / $\left(\mathrm{mg} \mathrm{L}^{-1}\right)$} & \multirow{2}{*}{$\begin{array}{l}\text { Mean } \pm \text { SD / } \\
\left(\mathrm{mg} \mathrm{L}^{-1}\right)\end{array}$} & \multirow{2}{*}{$\begin{array}{c}\mathrm{RSD} / \\
\%\end{array}$} & \multirow{2}{*}{ Recovery / \% } \\
\hline & 1 & 2 & 3 & 4 & 5 & 6 & 7 & 8 & 9 & 10 & 11 & 12 & 13 & 14 & 15 & & & \\
\hline $\mathrm{Ag}$ & 0.06 & 0.04 & 0.05 & 0.06 & 0.05 & 0.05 & 0.06 & 0.04 & 0.06 & 0.06 & 0.06 & 0.07 & 0.06 & 0.16 & 0.05 & $0.06 \pm 0.03$ & 50 & 35 \\
\hline As & 2.3 & 2.1 & 2.3 & 2.3 & 1.8 & 2.1 & 2.0 & 2.0 & 2.3 & 2.4 & 2.4 & 2.6 & 2.0 & 2.1 & 2.3 & $2.2 \pm 0.2$ & 10 & 54 \\
\hline $\mathrm{Ba}$ & 2.3 & 2.4 & 1.6 & 1.4 & 1.0 & 0.2 & 4.1 & 0.2 & 2.0 & 0.2 & 1.8 & 0.2 & 1.1 & 0.2 & 1.4 & $1.3 \pm 1.1$ & 83 & 2 \\
\hline $\mathrm{Cr}$ & 0.1 & 0.1 & 0.1 & 0.2 & 0.0 & 0.1 & 0.5 & 0.1 & 0.1 & 0.1 & 0.1 & 0.2 & 0.1 & 0.1 & 0.1 & $0.1 \pm 0.1$ & 92 & 0.9 \\
\hline Cs & 0.4 & 0.4 & 0.4 & 0.5 & 0.8 & 0.4 & 0.5 & 0.5 & 0.5 & 0.4 & 0.4 & 0.7 & 0.6 & 1.1 & 0.3 & $0.5 \pm 0.2$ & 36 & 14 \\
\hline $\mathrm{Cu}$ & 0.05 & 0.06 & 0.06 & 0.06 & 0.07 & 0.07 & 0.07 & 0.09 & 0.1 & 0.05 & 0.12 & 0.09 & 0.1 & 0.1 & 0.07 & $0.08 \pm 0.02$ & 25 & 1.5 \\
\hline $\mathrm{Fe}$ & 14 & 11 & 10 & 10 & 10 & 9 & 10 & 10 & 10 & 10 & 10 & 10 & 17 & 13 & 11 & $11 \pm 2$ & 18 & 0.2 \\
\hline $\mathrm{Ga}$ & 1.6 & 1.3 & 1.7 & 1.4 & 1.5 & 1.5 & 1.5 & 1.5 & 1.4 & 1.7 & 1.5 & 1.6 & 1.6 & 1.6 & 1.7 & $1.5 \pm 0.1$ & 8 & 20 \\
\hline $\mathrm{Li}$ & 0.4 & 0.2 & 0.3 & 0.1 & 0.7 & 0.3 & 0.3 & 0.7 & 0.3 & 0.4 & 0.3 & 0.3 & 0.8 & 0.9 & 0.5 & $0.4 \pm 0.2$ & 56 & 4 \\
\hline $\mathrm{Mg}$ & 0.9 & 0.7 & 1.3 & 0.9 & 0.6 & 0.8 & 0.8 & 1.0 & 1.1 & 0.9 & 1.9 & 1.0 & 0.9 & 1.2 & 1.2 & $1.0 \pm 0.3$ & 32 & 0.4 \\
\hline $\mathrm{Mn}$ & 0.09 & 0.06 & 0.08 & 0.07 & 0.05 & 0.05 & 0.05 & 0.06 & 0.08 & 0.06 & 0.09 & 0.06 & 0.07 & 0.06 & 0.06 & $0.07 \pm 0.01$ & 14 & 0.1 \\
\hline $\mathrm{Ni}$ & 0.16 & 0.15 & 0.16 & 0.15 & 0.15 & 0.17 & 0.23 & 0.17 & 0.16 & 0.13 & 0.22 & 0.17 & 0.21 & 0.21 & 0.15 & $0.17 \pm 0.03$ & 18 & 4 \\
\hline $\mathrm{Pb}$ & 0.4 & 0.1 & 0.2 & 0.2 & 0.7 & 0.2 & 0.7 & 0.4 & 0.4 & 0.3 & 0.3 & 0.6 & 1.1 & 0.9 & 0.4 & $0.5 \pm 0.3$ & 65 & 6 \\
\hline $\mathrm{Rb}$ & 6.4 & 5.7 & 5.7 & 6.2 & 7.4 & 5.7 & 6.1 & 6.4 & 6.6 & 6.6 & 6.0 & 7.6 & 7.5 & 8.6 & 6.0 & $6.6 \pm 0.8$ & 13 & 34 \\
\hline $\mathrm{Se}$ & 0.21 & 0.23 & 0.16 & 0.31 & 0.19 & 0.22 & 0.28 & 0.26 & 0.31 & 0.24 & 0.28 & 0.3 & 0.28 & 0.31 & 0.24 & $0.25 \pm 0.05$ & 20 & 8 \\
\hline $\mathrm{Sr}$ & 0.13 & 0.09 & 0.11 & 0.1 & 0.07 & 0.09 & 0.15 & 0.1 & 0.13 & 0.1 & 0.18 & 0.1 & 0.13 & 0.1 & 0.13 & $0.11 \pm 0.03$ & 27 & 0.7 \\
\hline V & 10 & 10 & 11 & 10 & 7 & 9 & 9 & 9 & 11 & 11 & 11 & 12 & 8 & 7 & 10 & $10 \pm 1$ & 14 & 51 \\
\hline $\mathrm{Zn}$ & 1.8 & 1.3 & 1.8 & 1.5 & 2.1 & 1.7 & 2.2 & 2.7 & 2.4 & 1.7 & 4.8 & 3.2 & 7.5 & 4.4 & 2.3 & $3 \pm 2$ & 60 & 19 \\
\hline$\overline{\mathrm{Al}}$ & 153 & 228 & 222 & 110 & 165 & 87 & 53 & 335 & 370 & 550 & 269 & 138 & 154 & 126 & 627 & $239 \pm 167$ & 70 & 1.0 \\
\hline $\mathrm{Si} /\left(\mathrm{g} \mathrm{L}^{-1}\right)$ & 18.9 & 18.7 & 19.6 & 17.9 & 17.7 & 21.6 & 20.3 & 20.1 & 16.1 & 19.9 & 23.0 & 23.7 & 19.1 & 21.2 & 14.7 & $19 \pm 2$ & 12 & 30 \\
\hline
\end{tabular}

SD: standard deviation; RSD: relative standard deviation.

substantiated by XRD analysis (see item "Zeolite characterization"), and the cation exchange capacity

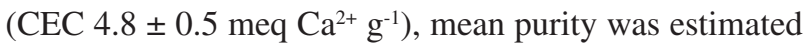
at $83 \pm 8 \%$. Similar values $(82 \pm 2 \%)$ were reported by Cardoso et al..$^{13}$ for the same process. It is important to note that some tests ( 1 and 13) can produce a high-purity zeolite (up to $97 \%$ ) with an excellent yield ( $0.39 \mathrm{~g}$ of zeolite per $\mathrm{g}$ of fly ash).

In CEC testing, in addition to calcium ions, the concentration of sodium ions exchanged was also monitored, obtaining a mean value of $6.6 \pm 0.6 \mathrm{meq} \mathrm{Na}^{+} \mathrm{g}^{-1}$. The average ratio between sodium and calcium CEC values $(1.4 \pm 2)$ indicates excess $\mathrm{Na}^{+}$in the solution, suggesting that part of the ion transferred to the solution was not a counterion in the zeolitic structure. ${ }^{38}$

\section{Zeolite characterization}

The morphology of zeolites Na-P1 and 4A synthesized in process A by SEM and typical images are shown in Figures $2 \mathrm{a}$ and 2b, respectively (see Figures S1 and S2 for all samples). Typical zeolite Na-P1 shapes, widely reported in other studies, ${ }^{6,13,33,39,40}$ were observed in all the tests performed (Figures 2a and S1). A noteworthy feature is the morphology consisting of secondary cauliflower-like aggregates measuring approximately $10 \mu \mathrm{m}$ (Figure S1, tests 10 and 14). These secondary aggregates are composed of small primary aggregates formed by cubic crystals with well-defined edges and anisotropic crystal growth, characteristic of the typical gismondine-like framework of this aluminosilicate ${ }^{41}$ as seen in the other tests (Figure S1). Figure $2 b$ (also see Figure S2) depicts the characteristic morphology of zeolite 4A observed in all tests, exhibiting clearly faceted cubes with a smooth surface ${ }^{13,29}$ and relatively uniform size distribution.

Based on the individual results of morphological analyses and CEC, the 15 syntheses for each type of zeolite were combined and characterized using only two samples, representative of zeolites Na-P1 and 4A. XRD confirmed the presence of a single crystalline phase (zeolite 4A) in the product obtained in the second step of process A (Figure S4), corroborating the other characterization results. The diffractogram (Figure S3) of the second product (IIA) confirmed zeolite Na-P1 as the major crystalline phase and indicated the presence of unreacted quartz and mullite, originally present in the fly ash (Table S1 and Figure S8). The low solubility of these minerals in $\mathrm{NaOH}$ and likely saturation of the reactive medium with $\mathrm{Si}$ and Al explain this behavior. According to Bieseki et al., ${ }^{42}$ the original quartz present in the coal ash did not react during zeolite formation. 
Table 3. Characterization of the solid (zeolitic product, 4A) resulting from the second step of process A

\begin{tabular}{|c|c|c|c|c|c|c|c|}
\hline \multirow{3}{*}{ Test } & \multirow{3}{*}{$\begin{array}{l}\text { Fly ash } \\
\mathrm{m}_{\mathrm{FA}} / \mathrm{g}\end{array}$} & \multicolumn{6}{|c|}{ Zeolitic product (IVA, 4A) } \\
\hline & & \multirow{2}{*}{$\mathrm{mP} / \mathrm{g}$} & \multirow[b]{2}{*}{$\mathrm{mZ} / \mathrm{g}$} & \multicolumn{3}{|c|}{ CEC } & \multirow{2}{*}{$\begin{array}{l}\text { Purity } \\
\text { PZ / \% }\end{array}$} \\
\hline & & & & $\begin{array}{c}\mathrm{Ca}^{2+} / \\
\left(\mathrm{meq} \mathrm{g}^{-1}\right)\end{array}$ & $\begin{array}{c}\mathrm{Na}^{+} / \\
\left(\mathrm{meq} \mathrm{g}^{-1}\right)\end{array}$ & $\mathrm{Na} / \mathrm{Ca}$ & \\
\hline 1 & 15.04 & 8.1 & 7.8 & 5.6 & 5.7 & 1.0 & 97 \\
\hline 2 & 15.00 & 8.2 & 6.2 & 4.4 & 6.0 & 1.4 & 76 \\
\hline 3 & 15.01 & 7.4 & 6.4 & 5.0 & 6.2 & 1.2 & 86 \\
\hline 4 & 15.09 & 7.6 & 6.3 & 4.8 & 6.0 & 1.3 & 83 \\
\hline 5 & 15.05 & 5.3 & 4.0 & 4.4 & 6.9 & 1.6 & 76 \\
\hline 6 & 15.00 & 7.1 & 5.4 & 4.4 & 6.3 & 1.4 & 76 \\
\hline 7 & 15.00 & 6.3 & 5.8 & 5.4 & 6.9 & 1.3 & 93 \\
\hline 8 & 15.03 & 7.0 & 5.8 & 4.8 & 6.3 & 1.3 & 83 \\
\hline 9 & 15.01 & 7.3 & 6.0 & 4.8 & 7.5 & 1.6 & 83 \\
\hline 10 & 15.00 & 6.4 & 5.6 & 5.1 & 6.2 & 1.2 & 88 \\
\hline 11 & 14.97 & 6.2 & 4.3 & 4.0 & 6.5 & 1.6 & 69 \\
\hline 12 & 14.99 & 6.3 & 5.3 & 4.9 & 7.6 & 1.6 & 84 \\
\hline 13 & 15.03 & 7.9 & 7.6 & 5.6 & 7.5 & 1.3 & 97 \\
\hline 14 & 15.08 & 6.0 & 4.3 & 4.2 & 7.1 & 1.7 & 72 \\
\hline 15 & 15.06 & 7.9 & 7.0 & 5.1 & 6.6 & 1.3 & 88 \\
\hline Mean & 15.02 & 7.0 & 5.9 & 4.8 & 6.6 & 1.4 & 83 \\
\hline SD & 0.03 & 0.9 & 1.1 & 0.5 & 0.6 & 0.2 & 8 \\
\hline RSD / \% & 0.2 & 12 & 19 & 10 & 9 & 13 & 10 \\
\hline
\end{tabular}

$\mathrm{m}_{\mathrm{FA}}$ : initial ash mass; $\mathrm{mP}$ : mass of the product; $\mathrm{mZ}$ : zeolite mass in the product; $\mathrm{CEC}$ : cation exchange capacity; PZ: semi-quantitative zeolite content in the products; SD: standard deviation; RSD: relative standard deviation.

(a)

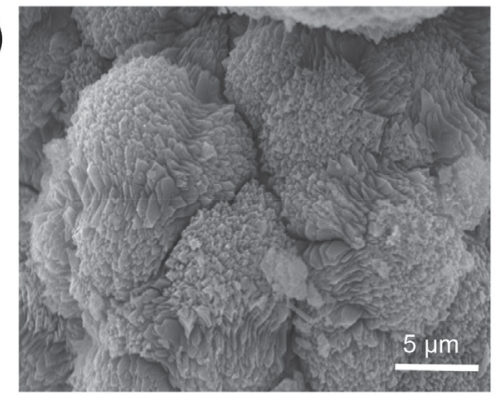

Test 2

(b)

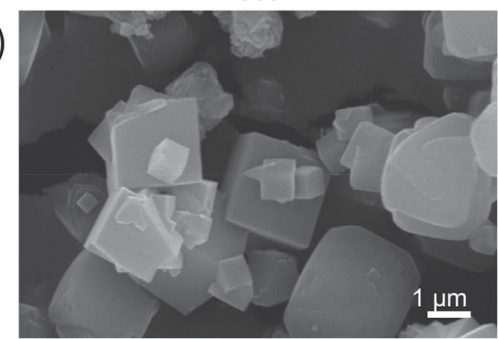

Test 12

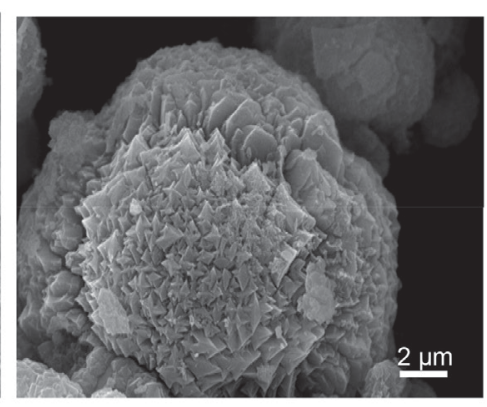

Test 8

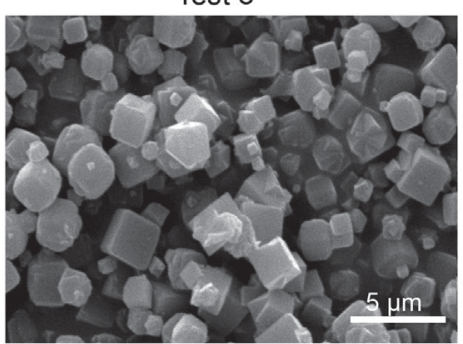

Test 14

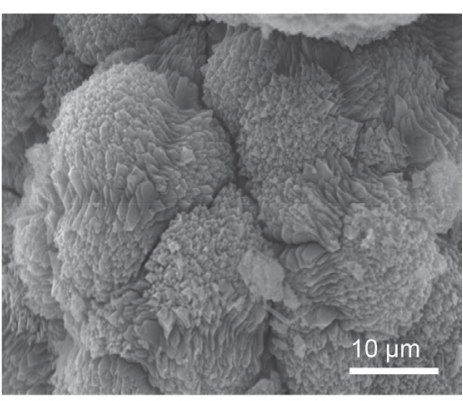

Test 9

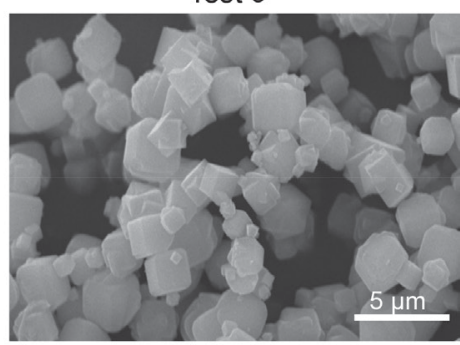

Test 15

Figure 2. SEM images of zeolites (a) Na-P1 and (b) 4A obtained by synthesis process A.

The chemical composition of zeolites Na-P1 and 4A obtained in process A are shown in Figure 3 (also see Table S2). As expected, zeolite Na-P1 displayed higher concentrations of most of the elements studied. The formation of this zeolite in the first step of the process and its impurity due to mixing with unreacted residual ash explain the retention of most of the contaminants present in the precursor ash (Table S2). High levels of 
Fe (8.5\%), Ca (2.8\%) and K (1.3\%) were recorded, with intermediate concentrations of $\mathrm{Mg}, \mathrm{Mn}, \mathrm{Sr}, \mathrm{Ni}, \mathrm{Ba}, \mathrm{Rb}, \mathrm{Zn}$, $\mathrm{Cr}$ and $\mathrm{Li}$ (1.930 to $50 \mathrm{mg} \mathrm{kg}^{-1}$ ), considered contaminants. Mainganye et al. ${ }^{43}$ found similar $\mathrm{Ba}, \mathrm{Cu}, \mathrm{Ni}$ and $\mathrm{Pb}$ levels in zeolite Na-P1 obtained from South African coal fly ash to those reported here. By contrast, the major contaminants for zeolite $4 \mathrm{~A}$ were $\mathrm{K}\left(0.3 \%\right.$ or $\left.3,404 \mathrm{mg} \mathrm{kg}^{-1}\right)$ and $\mathrm{Ca}$ $\left(1,358 \mathrm{mg} \mathrm{kg}^{-1}\right)$, and the only minor contaminants exhibiting concentrations $>50 \mathrm{mg} \mathrm{kg}^{-1}$ were $\mathrm{Ti}, \mathrm{Fe}, \mathrm{Mg}$ and Ba. These results were expected and corroborate findings in similar studies. ${ }^{5,28,44,45}$ It is important to underscore the low levels $\left(<1 \mathrm{mg} \mathrm{kg}^{-1}\right)$ recorded for most of the highly toxic elements (As, $\mathrm{Cr}, \mathrm{Se}$, etc.). These results indicate the potential use of zeolite $4 \mathrm{~A}$ in applications with more stringent contaminant standards (i.e., biomaterials, zeolite fertilizers, etc.).

\section{Synthesis using process B}

\section{Extraction step and formation of the low-grade zeolite}

Table 4 shows the characterization of the extracts (IB) resulting from the first step of synthesis, as well as the residual ash (IIB) and low-grade zeolitic product
(VB) obtained in process $\mathrm{B}$, according to the original methodology of Hollman et al. ${ }^{18}$ Despite of being performed in an open reactor, the extraction step produced a slight reduction in the volume of the extract $(-14 \%)$ when compared to process A, likely due to the lower temperatures and shorter extraction times $\left(85^{\circ} \mathrm{C}, 2 \mathrm{~h}\right)$. All tests showed greater extraction of $\mathrm{Si}(1.86 \pm 0.08 \mathrm{~g})$ in relation to $\mathrm{Al}$ $(0.137 \pm 0.002 \mathrm{~g})$, corresponding to recovery percentages of around $\mathrm{R}_{\mathrm{Si}} 20 \%$ and $\mathrm{R}_{\mathrm{Al}} 4 \%$ of the amount present in the ash, respectively. Slightly higher recovery values $\left(\mathrm{R}_{\mathrm{Si}} 25 \% ; \mathrm{R}_{\mathrm{Al}} 5 \%\right)$ were obtained when compared to levels of amorphous $\mathrm{Si}$ and $\mathrm{Al}$ present in the fly ash. The fact that the amount of Si extracted was 14 times greater than that of $\mathrm{Al}$ can be explained by the different concentrations and reactivity of these elements in the ash, as previously discussed. A comparison of these results (Table 4) with those obtained in process A (Table 1) shows different behavior among the elements, with lower extraction of $\mathrm{Si}(-50 \%)$ and a significant increase for $\mathrm{Al}(+300 \%)$. These findings suggest important variations in $\mathrm{Al}$ solubility throughout the extraction step, previously reported by other authors. ${ }^{13,33}$ With respect to reproducibility of the extraction
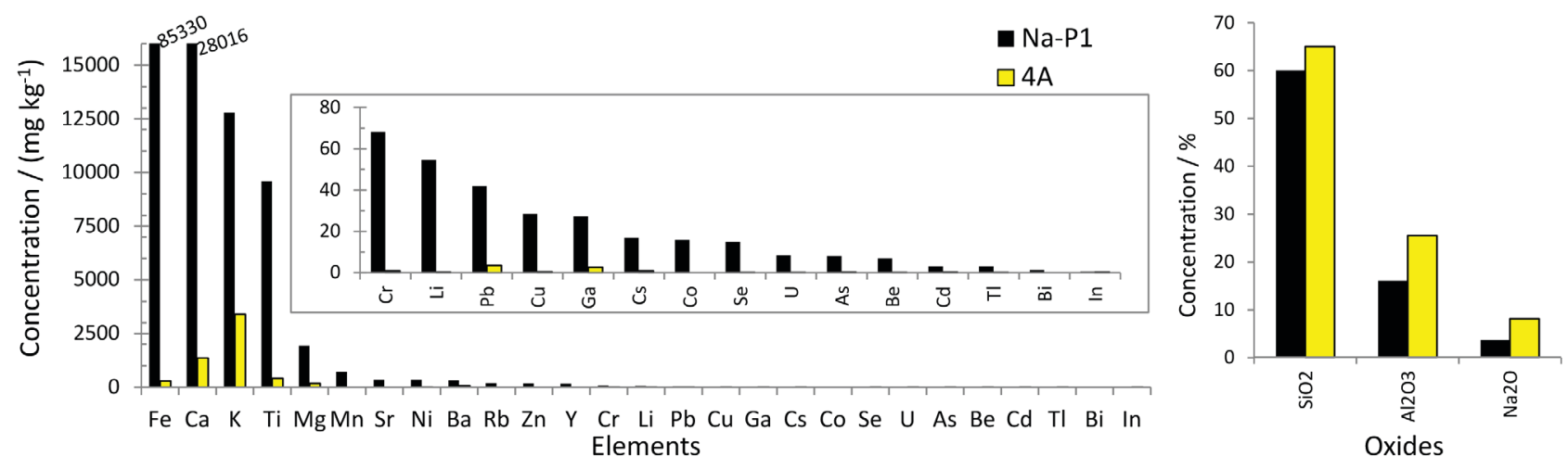

Figure 3. Average concentrations obtained for the majority, minority and trace elements in synthetic zeolites using process A. Results obtained by XRF (majority and minority elements) and ICP-MS (trace elements).

Table 4. Characterization and yields of the solids and extract obtained in process B

\begin{tabular}{|c|c|c|c|c|c|c|c|c|c|c|c|c|c|c|c|c|c|}
\hline \multirow{4}{*}{ Test } & \multirow{4}{*}{$\begin{array}{c}\text { Fly ash } \\
\begin{array}{c}\mathrm{m}_{\mathrm{FA}} / \\
\mathrm{g}\end{array} \\
\end{array}$} & \multirow{4}{*}{$\begin{array}{c}\text { Residual- } \\
\text { ash } \\
\begin{array}{c}\text { mRA / } \\
\mathrm{g}\end{array} \\
\end{array}$} & \multirow{2}{*}{\multicolumn{7}{|c|}{$\begin{array}{c}\text { Extract } \\
\text { (IB) }\end{array}$}} & \multicolumn{8}{|c|}{ Zeolitic product } \\
\hline & & & & & & & & & & \multicolumn{4}{|c|}{ Na-P1 (VB) } & \multicolumn{4}{|c|}{ 4A (IVB) } \\
\hline & & & \multirow{2}{*}{$\begin{array}{c}\text { Volume } \\
\mathrm{V}_{\mathrm{Ex}} / \\
\mathrm{mL}\end{array}$} & \multicolumn{2}{|c|}{ Element mass } & \multicolumn{2}{|c|}{ Si recovery } & \multicolumn{2}{|c|}{$\mathrm{Al}$ recovery } & \multirow[b]{2}{*}{$\begin{array}{c}\mathrm{mP} / \\
\mathrm{g}\end{array}$} & \multirow{2}{*}{$\begin{array}{c}\mathrm{mZ} / \\
\mathrm{g}\end{array}$} & \multirow{2}{*}{$\begin{array}{c}\mathrm{CEC} \\
\mathrm{NH}_{4}^{+} / \\
\left(\mathrm{meq} \mathrm{g}^{-1}\right)\end{array}$} & \multirow{2}{*}{$\begin{array}{c}\text { Purity } \\
\text { PZ/ } \\
\% \\
\end{array}$} & \multirow[b]{2}{*}{$\begin{array}{c}\mathrm{mP} / \\
\mathrm{g}\end{array}$} & \multirow[b]{2}{*}{$\begin{array}{c}\mathrm{mZ} / \\
\mathrm{g}\end{array}$} & \multirow{2}{*}{$\begin{array}{c}\mathrm{CEC} \\
\mathrm{Ca}^{2+} / \\
\left(\mathrm{meq} \mathrm{g}^{-1}\right)\end{array}$} & \multirow{2}{*}{$\begin{array}{c}\text { Purity } \\
\text { PZ/ } \\
\% \\
\end{array}$} \\
\hline & & & & $\begin{array}{c}\mathrm{m}_{\mathrm{Si} \text { Ext. }} / \\
\mathrm{g}\end{array}$ & $\overline{\mathrm{m}_{\mathrm{AlExt.}} /}$ & $\begin{array}{c}\text { Total / } \\
\%\end{array}$ & $\begin{array}{c}\text { Amorphous / } \\
\%\end{array}$ & $\begin{array}{c}\text { Total / } \\
\%\end{array}$ & $\begin{array}{c}\text { Amorphous / } \\
\%\end{array}$ & & & & & & & & \\
\hline 1 & 30.00 & 24.1 & 253 & 1.90 & 0.137 & 20.0 & 25 & 3.9 & 4.9 & 24.8 & 15.1 & 2.8 & 61 & 7.6 & 5.6 & 4.3 & 74 \\
\hline 2 & 30.00 & 24.7 & 263 & 1.91 & 0.138 & 20.1 & 25 & 3.9 & 5.0 & 24.5 & 14.4 & 2.7 & 59 & 7.6 & 5.5 & 4.2 & 72 \\
\hline 3 & 30.00 & 25.6 & 258 & 1.77 & 0.135 & 18.6 & 23 & 3.8 & 4.9 & 25.1 & 15.9 & 2.9 & 63 & 7.1 & 5.5 & 4.5 & 78 \\
\hline Mean & 30.00 & 24.8 & 258 & 1.86 & 0.137 & 19.5 & 24 & 3.9 & 4.9 & 24.8 & 15.1 & 2.8 & 61 & 7.4 & 5.5 & 4.3 & 75 \\
\hline SD & 0.01 & 0.8 & 5 & 0.08 & 0.002 & 0.8 & 1 & 0.0 & 0.1 & 0.3 & 0.7 & 0.1 & 2 & 0.3 & 0.1 & 0.2 & 3 \\
\hline RSD & 0.03 & 3 & 2 & 4.2 & 1.1 & 4.2 & 4.2 & 1.1 & 1.1 & 1 & 5 & 4 & 4 & 4 & 1 & 4 & 4 \\
\hline
\end{tabular}

$\mathrm{m}_{\mathrm{FA}}$ : initial ash mass; $\mathrm{mRA}$ : residual ash mass; $\mathrm{V}_{\mathrm{Ex}}$ : extract volume; $\mathrm{m}_{\mathrm{Si} \mathrm{Ex}}$ and $\mathrm{m}_{\mathrm{AlEx}}$ : mass of $\mathrm{Si}$ and $\mathrm{Al}$ extracted; $\mathrm{Si}$ and $\mathrm{Al}$ recoveries (total $/ \%$ ): calculated based on the extracted mass of these elements in relation to their total contents in the ash (presented in the sequence); Si and Al Recovery (amorphous / \%): calculated based on the extracted mass of these elements in relation to their contents in the amorphous phase of the ash (Table S1); mP: mass of the product; mZ: zeolite mass in the product; CEC: cation exchange capacity; PZ: semi-quantitative zeolite content in the products; SD: standard deviation; RSD: relative standard deviation. 
step, low coefficients of variation were observed for both $\mathrm{Si}$ (standard deviation 4\%) and $\mathrm{Al}(1 \%)$. These values are significantly lower than those reported for process A (Table $1, \mathrm{n}=15$ ); however, a direct comparison cannot be made due to the different number of replicates $(n=3)$.

With respect to the solubility of $\mathrm{Al}$, according to the literature ${ }^{46,47}$ different leaching tests were applied to coal fly ash and all the results showed low solubilization for this element, particularly when considering its abundance in fly ash. These low leaching rates are related to the slow dissolution of the crystalline aluminosilicate phases and glassy matrix. ${ }^{46}$ The leachability of $\mathrm{Al}$ is strongly $\mathrm{pH}$ dependent, with regions of low solubility (around 5 to 7) attributed to solubility constraints of amorphous $\mathrm{Al}(\mathrm{OH})_{3}$ species present in fly ash. Solubility increases significantly in the most acidic $(\mathrm{pH}<4)$ and most basic $\mathrm{pH}$ ranges ( $\mathrm{pH}$ 9-11 range). In alkaline environments, $\mathrm{Al}$ is leached as aluminate $\left(\mathrm{Al}(\mathrm{OH})_{4}\right) \cdot{ }^{46,48,49}$ However, leaching declines at $\mathrm{pH}$ ca. 11.5 due to ettringite precipitation. ${ }^{46,50}$ This behavior is consistent with the low Al solubility observed in our extracts due to the high alkaline conditions ( $\mathrm{pH}>14)$.

Data from the literature ${ }^{46,51}$ indicates that glass is the main Si-bearing phase leached. Silicon is released slowly, but the glass dissolution rate is enhanced by the presence of $\mathrm{OH}^{-}$in solution. Si dissolution declines between $\mathrm{pH} 8$ and 10 and increases towards the acidic and alkaline ends of the $\mathrm{pH}$ range, ${ }^{46}$ which may explain the higher solubility observed under the conditions studied here.

The mass of the obtained solid product $(\mathrm{mP})$ was $24.8 \pm 0.3 \mathrm{~g}$, corresponding to $0.83 \pm 0.01 \mathrm{~g}$ of product per $\mathrm{g}$ of ash, with a CEC value of $2.8 \pm 0.1$ meq $\mathrm{NH}_{4}^{+} \mathrm{g}^{-1}$. Considering zeolite Na-P1 as the main phase present in the solid (item "Characterization of the zeolites and residual ash" and Figure S5), its purity is estimated at $61 \pm 2 \%$, implying a yield of $0.50 \mathrm{~g}$ of zeolite per $\mathrm{g}$ of fly ash. These results are similar to those reported by Cardoso et al. ${ }^{13}$ and lower than those recorded for process A (Table 1).

\section{Synthesis of the high-purity zeolite (second step)}

The results of the synthesis of zeolite $4 \mathrm{~A}$ (IVB) using the extract and sodium aluminate alkaline solution $\left(2.0 \mathrm{~mol} \mathrm{~L}^{-1}\right)$ to adjust the $\mathrm{Si} / \mathrm{Al}$ molar ratio are also displayed in Table 4. The mean mass of the solid product $(\mathrm{mP})$ was $7.4 \pm 0.3 \mathrm{~g}$ and CEC $4.3 \pm 0.2 \mathrm{meq} \mathrm{Ca}^{2+} \mathrm{g}^{-1}$, corresponding to purity of $75 \pm 3 \%$ in zeolite $4 \mathrm{~A}$. This was the only phase identified (Figure S6), though less pure than its counterpart in process A $(83 \%)$. These values result in low yield for this zeolite when compared to the amount of fly ash used in the process ( $0.18 \mathrm{~g}$ of zeolite per $\mathrm{g}$ of fly ash). These values corroborate the other results, indicating better performance in that process. Nevertheless, they can be considered adequate and competitive for the application of zeolite $4 \mathrm{~A}$ in the detergent industry as a substitute for sodium tripolyphosphate, provided that the remaining parameters comply with the necessary requirements. ${ }^{13}$

\section{Characterization of the zeolites and residual ash}

Figures $4 \mathrm{a}$ and $4 \mathrm{~b}$ show SEM images, typical of the morphology of zeolites Na-P1 and 4A, respectively, (a)

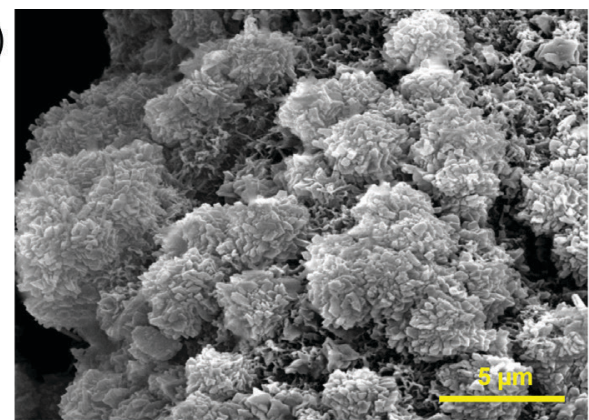

(b)

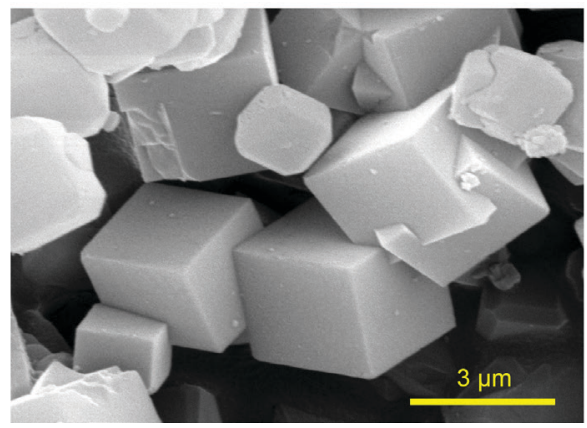

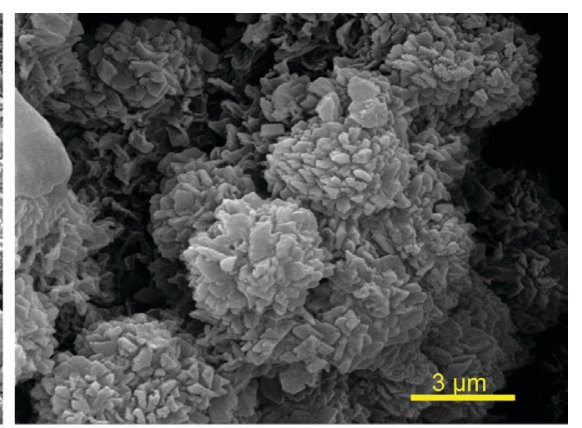

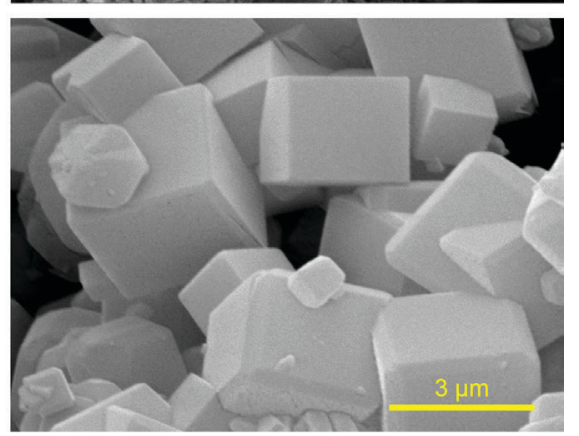

Figure 4. SEM images of zeolites (a) Na-P1 and (b) 4A obtained by process B. 
obtained in process B. Shapes were similar in the three tests for both zeolites Na-P1 (Figure 4a) and 4A (Figure 4b) and did not differ from the homologous zeolites in the fifteen tests of process A (Figures S1 and S2). It is important to note the presence of different-sized cubes $(447 \mathrm{~nm}$ heterogeneous.

The chemical compositions of these zeolites are shown in Figure 5 (see Table S2 for details). Similar behavior to that mentioned in the item "Zeolite characterization" was observed, with greater contamination of zeolite Na-P1 compared to 4A. The high concentrations of the component elements ( $\mathrm{Si}, \mathrm{Al}$ and $\mathrm{Na}$ ) in zeolite $4 \mathrm{~A}$ were also noteworthy, in proportions that confirm its structure $(\mathrm{Si} / \mathrm{Al}$ ratio $=1.0$, $\mathrm{Na} / \mathrm{Al}$ ratio $=1.1)$. The major contaminants of zeolite 4A were Ti $\left(0.71 \%\right.$ or $\left.7.072 \mathrm{mg} \mathrm{kg}^{-1}\right), \mathrm{K}\left(1.350 \mathrm{mg} \mathrm{kg}^{-1}\right)$ and $\mathrm{Ca}\left(638 \mathrm{mg} \mathrm{kg}^{-1}\right)$, whereas no minor elements were found at levels $>50 \mathrm{mg} \mathrm{kg}^{-1}$ and several were not detected. However, it is important to underscore the high selenium content $\left(33 \mathrm{mg} \mathrm{kg}^{-1}\right)$ in all the products synthesized in this study. High levels of Fe (3.1\%) and K (1.5\%) were once again observed in zeolite Na-P1, with intermediate concentrations of $\mathrm{Mg}, \mathrm{Mn}, \mathrm{Sr}, \mathrm{Ni}, \mathrm{Ba}, \mathrm{Rb}, \mathrm{Zn}, \mathrm{Cr}, \mathrm{Li}$ and $\mathrm{Pb}\left(5264\right.$ to $\left.>50 \mathrm{mg} \mathrm{kg}^{-1}\right)$.

Figure 5 shows the chemical composition of residual ash (IIB), the solid produced in the first step of synthesis (Figure 1b). As expected, it exhibits Si (25.1\%) and Al $(8.5 \%)$ depletion and $\mathrm{Na}$ enrichment $(7.7 \%)$ when compared to the original ash (Table S1) due to solubilization during extraction in alkaline medium $(\mathrm{NaOH})$. The simultaneous presence of the three zeolite component elements makes this material conducive to synthesis. However, major contaminants remain in $\mathrm{Fe}(3.1 \%), \mathrm{Ca}(2.3 \%)$ and $\mathrm{K}(1.5 \%)$, in addition to significant concentrations of several minor elements $\left(>50 \mathrm{mg} \mathrm{kg}^{-1}\right)$. These results explain the greater contamination of zeolite Na-P1 in the second step of this process. With respect to levels of the elements in the to $3.72 \mu \mathrm{m}$ ) with smooth surfaces, making sample size

residual and original ash (Table S1), some minor / trace elements ( $\mathrm{Ni}, \mathrm{Mg}, \mathrm{Ti}, \mathrm{Ca}, \mathrm{Sr}$ and $\mathrm{Cu}$ ) were concentrated in the former (ratio > 1.0), with low leaching into the alkaline solution. By contrast, $\mathrm{Ga}, \mathrm{V}, \mathrm{Pb}, \mathrm{Cs}, \mathrm{Rb}, \mathrm{As}$ and $\mathrm{Cd}$ were depleted (ratio < 0.7) in the residual ash, showing high mobility and the potential to contaminate the high-purity zeolitic product (zeolite 4A). These elements were likely associated with amorphous phases, which are more easily dissolved by the alkaline medium. The behavior of mineral phases in alkaline solution can be verified by comparing the diffractograms of original and residual ash after leaching (Figures S7 and S8), indicating that quartz and mullite remain as major phases. Conversion of this residue into zeolite Na-P1 also significantly reduces the amount of solid waste resulting from the zeolitization process, which is far greater than in process A. ${ }^{13}$ This additional step eliminates a highly-contaminated waste product and generates one that can be employed, for example, to treat acid mine drainage, ${ }^{6,52}$ swine wastewater ${ }^{13}$ and electroplating wastewater, ${ }^{39}$ as well as in the adsorption of ammoniacal nitrogen from tannery and landfill effluents, ${ }^{53}$ among other applications.

Characterization of the effluents generated in the two processes

Table 5 shows the characterization of the effluents generated in the two synthesis processes (IIIA and IIIB) and the wastewater discharge standards for the relevant controlled elements. ${ }^{37,54}$ As expected, high sodium levels of 81,000 and $75,000 \mathrm{mg} \mathrm{L}^{-1}$ were recorded in effluents IIIA and IIIB, respectively. These values are consistent with the concentrations of the $\mathrm{NaOH}$ solutions used in the extraction and synthesis step of each process $\left(3.0\right.$ and $2.0 \mathrm{~mol} \mathrm{~L}^{-1}$, respectively). With the exception of $\mathrm{Al}$ (ca. $690 \mathrm{mg} \mathrm{L}^{-1}$ ) and $\mathrm{K}$ (ca. $170 \mathrm{mg} \mathrm{L}^{-1}$ ), levels of all the remaining elements were $<6 \mathrm{mg} \mathrm{L}^{-1}$ in both effluents. Only $\mathrm{Ag}, \mathrm{V}, \mathrm{Rb}, \mathrm{Fe}, \mathrm{Ca}$, $\mathrm{Ga}, \mathrm{Si}$ and $\mathrm{Zn}$ were found in concentrations $>1 \mathrm{mg} \mathrm{L}^{-1}$. High
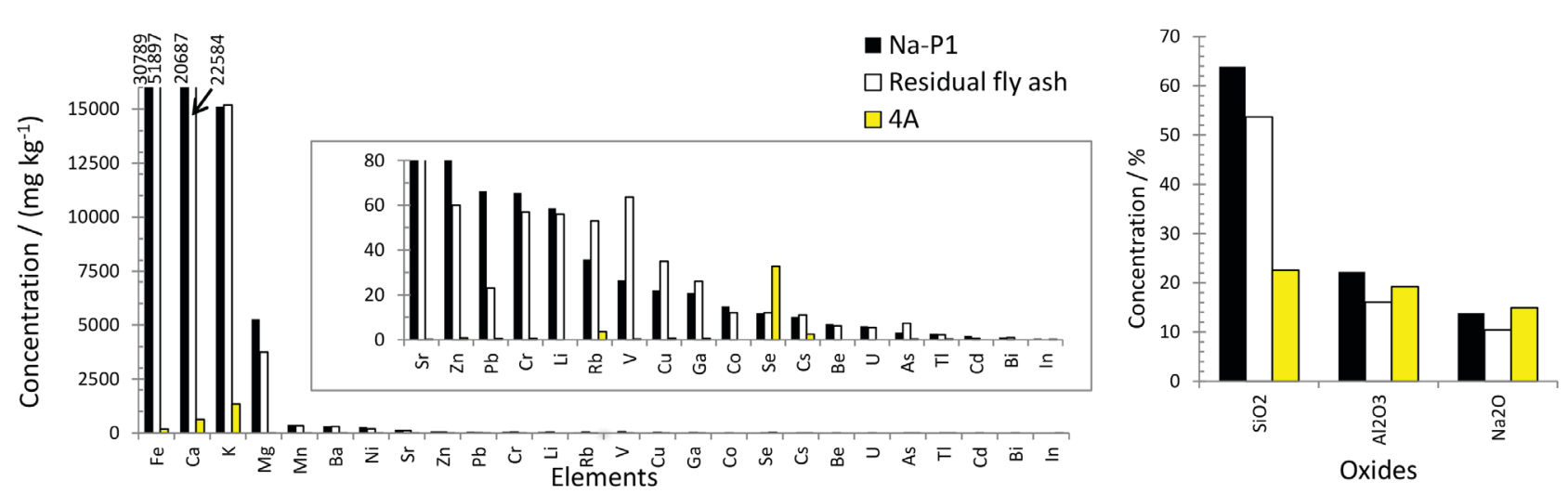

Figure 5. Average concentrations recorded for majority, minority and trace elements in solid products obtained by process B, obtained by XRF (majority and minority elements) and ICP-MS (trace elements). 
levels of elements such as $\mathrm{V}, \mathrm{Rb}$ and Fe were observed in the extracts of synthesis conducted via process A (Table 2). Despite the decline in their concentrations (ca. $4 \times$ ), they still stand out in relation to the remaining elements. The low Si levels (ca. $1.1 \mathrm{mg} \mathrm{L}^{-1}$ ), especially when compared to $\mathrm{Al}$, suggest good atom efficiency for this element. Contents of most of the elements studied were higher in the effluent from process B, particularly Ag, As, Cs, V and Rb, with levels at least two-fold greater than in process A. Ag content was ca. 40 times higher than in process B. These results were unexpected because extraction in process A was more prolonged, suggesting different and more complex solubilization/precipitation mechanisms between the elements. This difference in behavior was evident for $\mathrm{Si}$ and $\mathrm{Al}$ in the extracts of both processes.

Despite the low concentrations recorded, Al, V and As levels were ca. 70, 6 and 2 times higher than the wastewater discharge standard allowed under Brazilian legislation..$^{33,44}$

Silver exceeded the limit (12 times) only in the effluent from process B and chromium (1.3 times) only in process A. Ferrarini et al..$^{5}$ also reported higher As content than legally stipulated in a study using a synthesis process similar to process A. These results indicate the need for proper treatment before disposing these effluents, which would make the synthesis process more expensive.

However, the high sodium content (75 and $81 \mathrm{~g} \mathrm{~L}^{-1}$ ) favors the reuse of these effluents in zeolitization. In addition to reducing the volume of the effluent generated, reuse precludes the need for its treatment before disposal, thereby lowering the costs associated with this process. Dufour et al. ${ }^{55}$ used wastewater rich in $\mathrm{Na}$ and $\mathrm{Al}$ in feedstock for zeolite $13 \mathrm{X}$ synthesis.

\section{Zeolite contamination between the two synthesis processes}

Comparison between Figures 3 and 5 and Table S2 shows similarities for most of the elements investigated. Exceptions are evident for elements such as $\mathrm{Ba}, \mathrm{Mg}$ and Se in zeolite $4 \mathrm{~A}$, exhibiting differences 20 times greater between the two synthesis processes. For zeolite Na-P1 (exhibiting the highest number of quantified elements in the two synthesis processes), $t$-testing was applied to compare the two means ${ }^{56}$ to determine whether there were significant differences between the values provided by both synthesis processes. The findings demonstrate that for $65 \%$ of the elements analyzed, the results of the processes were statistically equal (at a 95\% confidence interval). Significant differences were only observed for As, Cs, $\mathrm{Mg}, \mathrm{Mn}, \mathrm{Ni}, \mathrm{Rb}, \mathrm{Se}$ and U. Of these, only Mg exhibited higher concentrations in synthesis process $\mathrm{B}$, whereas the highest levels of the remaining elements were obtained in
Table 5. Concentration of elements in the effluent generated by processes $\mathrm{A}$ and $\mathrm{B}$ and the maximum permissible limits (MPL)

\begin{tabular}{|c|c|c|c|c|c|c|}
\hline \multirow[t]{2}{*}{ Element } & \multicolumn{3}{|c|}{$\begin{array}{l}\text { Effluent (III) and } \\
\text { ratios / }\left(\mathrm{mg} \mathrm{L}^{-1}\right)\end{array}$} & \multicolumn{3}{|c|}{$\begin{array}{l}\text { Discharge limits and } \\
\text { ratios / }\left(\mathrm{mg} \mathrm{L}^{-1}\right)\end{array}$} \\
\hline & Process A & Process B & $\mathrm{B} / \mathrm{A}$ & $\mathrm{MPL}^{\mathrm{a}}$ & A/MPL & B/MPL \\
\hline $\mathrm{Ag}$ & 0.03 & 1.22 & 40.7 & 0.1 & 0.3 & 12 \\
\hline $\mathrm{Al}$ & 698 & 695 & 1.0 & 10 & 70 & 70 \\
\hline As & 0.56 & 0.95 & 1.7 & 0.5 & 1 & 2 \\
\hline $\mathrm{Ba}$ & 0.33 & 0.21 & 0.6 & 5 & 0.1 & 0.04 \\
\hline $\mathrm{Be}$ & & 0.02 & & & & \\
\hline $\mathrm{Ca}$ & & 1.67 & & & & \\
\hline $\mathrm{Cd}$ & & 0.03 & & 0.2 & & 0.2 \\
\hline Co & & 0.03 & & & & \\
\hline $\mathrm{Cr}$ & 0.13 & 0.05 & 0.4 & 0.1 & 1.3 & 0.5 \\
\hline Cs & 0.11 & 0.3 & 2.7 & & & \\
\hline $\mathrm{Cu}$ & 0.08 & 0.06 & 0.8 & 1 & 0.1 & 0.1 \\
\hline $\mathrm{Fe}$ & 2.22 & 1.75 & 0.8 & 15 & 0.1 & 0.1 \\
\hline $\mathrm{Ga}$ & 1.01 & 1.56 & 1.5 & & & \\
\hline In & & 0.02 & & & & \\
\hline K & & 175 & & & & \\
\hline $\mathrm{Li}$ & 0.1 & 0.19 & 1.9 & 10 & 0.01 & 0.02 \\
\hline $\mathrm{Mg}$ & 0.41 & 0.68 & 1.7 & & & \\
\hline $\mathrm{Mn}$ & 0.04 & 0.01 & 0.3 & 1 & 0.04 & 0.01 \\
\hline $\mathrm{Na}$ & 75,000 & 81,000 & 1.1 & & & \\
\hline $\mathrm{Ni}$ & 0.07 & 0.01 & 0.1 & 2 & 0.04 & 0.01 \\
\hline $\mathrm{Pb}$ & 0.13 & 0.09 & 0.7 & 0.5 & 0.3 & 0.2 \\
\hline $\mathrm{Rb}$ & 1.55 & 3.1 & 2.0 & & & \\
\hline $\mathrm{Se}$ & 0.14 & 0.18 & 1.3 & 0.3 & 0.5 & 0.6 \\
\hline $\mathrm{Si}$ & 1.05 & 1,21 & & & & \\
\hline $\mathrm{Si}$ & 1.05 & 1.21 & & & & \\
\hline $\mathrm{Sr}$ & 0.03 & 0.04 & 1.3 & & & \\
\hline $\mathrm{Tl}$ & nd & 0.03 & & & & \\
\hline $\mathrm{U}$ & nd & 0.03 & & & & \\
\hline V & 2.43 & 5.5 & 2.3 & 1 & 2 & 6 \\
\hline $\mathrm{Zn}$ & 1.66 & 0.77 & 0.5 & 5 & 0.3 & 0.2 \\
\hline
\end{tabular}

${ }^{a}$ Brazilian wastewater discharge standards. ${ }^{37,54}$ nd: not determined.

process A. It is important to underscore that applications for zeolite Na-P1 do not require high purity, meaning these differences may be negligible.

In relation to major elements, higher $\mathrm{Na}$ levels (ca. 4-fold) were recorded in zeolite Na-P1 resulting from process B. This is because obtaining zeolite Na-P1 via process $\mathrm{B}$ requires the alkaline reagent to be added twice. A slight discrepancy was observed in $\mathrm{Si}$ and $\mathrm{Al}$ concentrations in this same zeolite, particularly in the case of $\mathrm{Al}$, however, the ratio between these elements is within the expected range for zeolites with an intermediate $\mathrm{Si}$ content, such as Na-P1. ${ }^{57}$ Additionally, zeolite Na-P1 
produced using process A contained approximately 1.6 times more $\mathrm{Fe}$ than the zeolite obtained by process B. These data indicate greater solubilization of this element in process $\mathrm{B}$, meaning less Fe remains in the resulting zeolite.

Figure 6 shows the distribution percentages of the main elements in the zeolites and effluents of the two processes studied. Most of the elements showed significant incorporation into zeolite Na-P1, with the exception of $\mathrm{As}(72 \%)$ and $\mathrm{Ag}(61 \%)$, which were concentrated in zeolite $4 \mathrm{~A}$ produced via process A (Figure 6a). By contrast, in process B (Figure 6b), these two elements and $\mathrm{V}$ were most present in the effluent (>75\%), which also contained a significant portion $(>50 \%)$ of the other elements $(\mathrm{Ga}, \mathrm{Cs}$ and $\mathrm{Rb})$. These results confirm the low reactivity of most contaminants to alkaline extraction, which implies significant immobilization in the low-grade product, generated directly in the residual ash. However, the transfer of certain elements to the effluent in process $B$ requires further investigation since it impacts reuse of the wastewater, reducing the sustainability of the process.

The two synthesis processes studied here were compared using the methodology proposed by Cardoso et al. ${ }^{13}$ and expanded by including different parameters (Table 6). It is important to note that the initial conditions (coal fly ash mass, concentration and volume of the alkaline solution) differed in the two processes, and a direct comparison between the mass and volume of products and effluents was not possible. As such, the results were converted into yield, efficiency and ratios in order to enable a comparison. Table 6 summarizes the main data for processes A and B, as well as similar integrated processes reported in the literature. Data reported by Moreno et al. ${ }^{33}$ and Hollman et al..$^{18}$ who used fly ash from Spain (Puertollano Power Plant) and the Netherlands (information not provided) and processes similar to A and $\mathrm{B}$, respectively, were selected for this comparison.

As previously mentioned, process A generates extracts ca. 3 times richer in $\mathrm{Si}\left(19.493 \pm 2.391 \mathrm{mg} \mathrm{L}^{-1}\right)$ than process B $\left(7.235 \pm 330 \mathrm{mg} \mathrm{L}^{-1}\right)$, largely because the extraction times were 12 times longer. Nevertheless, since the decline in solvent volume during extraction differs, processes should be evaluated according to the percentage of $\mathrm{Si}$ extracted in relation to its content in the fly ash. The data in this table confirm good extraction efficiency (recovery) of 31 and $20 \%$ for processes $\mathrm{A}$ and $\mathrm{B}$, respectively, when compared to literature values. Moreno et al..$^{33}$ obtained intermediate efficiency (24\%) while Hollman et al. ${ }^{18}$ reported a far lower value $(6 \%)$, indicating that additional factors such as fly ash composition (amorphous Si content) and operating conditions ( $\mathrm{S} / \mathrm{L}$ ratio, extraction time and temperature) also influenced extraction. Low extraction efficiency was observed for $\mathrm{Al}$ in all the aforementioned studies ( 0.1 to
$4 \%$ ), demonstrating inferior mobility in relation to $\mathrm{Si}$, as previously discussed.

The Si-rich extracts were used in the synthesis of high-purity zeolite 4A, whereas the solid waste (process A) immediately generated a second zeolitic product (Na-P1) or proceeded to an additional synthesis step (process B), also producing zeolite Na-P1, which exhibited lower purity in both cases.

The data in Table 6 make possible to estimate the mass yield of the zeolites in relation to the amount of fly ash used in each process. In this study, process A generated more zeolite $4 \mathrm{~A}\left(0.38 \mathrm{~g} \mathrm{~g}^{-1}\right.$ ash $)$ and at significantly higher purity $(83 \pm 8 \%)$ than process $\mathrm{B}\left(0.18 \mathrm{~g} \mathrm{~g}^{-1}\right.$ ash; $\left.75 \pm 2 \%\right)$. Hollman et al. ${ }^{18}$ reported far less zeolite $4 \mathrm{~A}\left(0.06 \mathrm{~g} \mathrm{~g}^{-1}\right.$ ash $)$ with similar purity (79\%) to process B in the present study. Moreno et al..$^{33}$ reported the theoretical maximum amount of zeolite $4 \mathrm{~A}\left(0.41 \mathrm{~g} \mathrm{~g}^{-1}\right.$ ash) that would be obtained with full use of the Si extracted, which is very close to the mean experimental value for the 15 tests in process A, indicating excellent yield in the present study. Yields were higher and similar (0.40 to $0.57 \mathrm{~g} \mathrm{~g}^{-1}$ ash) for the low-grade zeolite (Na-P1), with better performance observed for process A, ca. $40 \%$ superior to that observed by Moreno et al. ${ }^{33} \mathrm{It}$ is important to note that this parameter does not adequately portray the reaction yield because additional feedstocks ( $\mathrm{NaOH}$ and secondary $\mathrm{Al}$ source) were added to the final product.

Another significant parameter in the comparison between synthesis processes is the use of $\mathrm{Si}$ and $\mathrm{Al}$ available in the feedstock (fly ash and secondary Al source) and incorporated into the zeolites. In process A, $60 \%$ of the available $\mathrm{Si}$ and $\mathrm{Al}$ were incorporated into the two produced zeolites, while lower incorporation of the two elements ( $44 \%$ of $\mathrm{Si}$ and $39 \% \mathrm{Al}$ ) was observed in process B. Data reported by Moreno et al..$^{33}$ indicate similar incorporation (53-54\%) to that of process A, while Hollman et al. ${ }^{18}$ found lower values for both elements (21-22\%). However, Cardoso et al. ${ }^{13}$ also obtained superior $\mathrm{Si}$ incorporation of 74 and $55 \%$ for processes A and B, respectively. Al incorporation was not analyzed by the authors. In general, better yields were observed for the elements in process A, in line with the behavior of the other parameters studied.

The sustainability of the processes should also be assessed in terms of effluent generation and its treatability / recyclability. Once again, direct comparison of the volumes generated was not possible due to the different liquid / solid $(\mathrm{L} / \mathrm{S})$ ratios used (3 to $10 \mathrm{~mL} \mathrm{~g}^{-1}$ ). As such, the effluent-tozeolite ratio $\left(\mathrm{E}_{\mathrm{Z}}\right)$ was used for comparison purposes, namely the ratio between the volume of effluent generated by the sum of the masses of the two zeolites (see item "Calculation of process yields and efficiencies" in the SI section). 
(a)

$$
\square 4 \mathrm{~A}
$$

- NaP1

田 Effluent

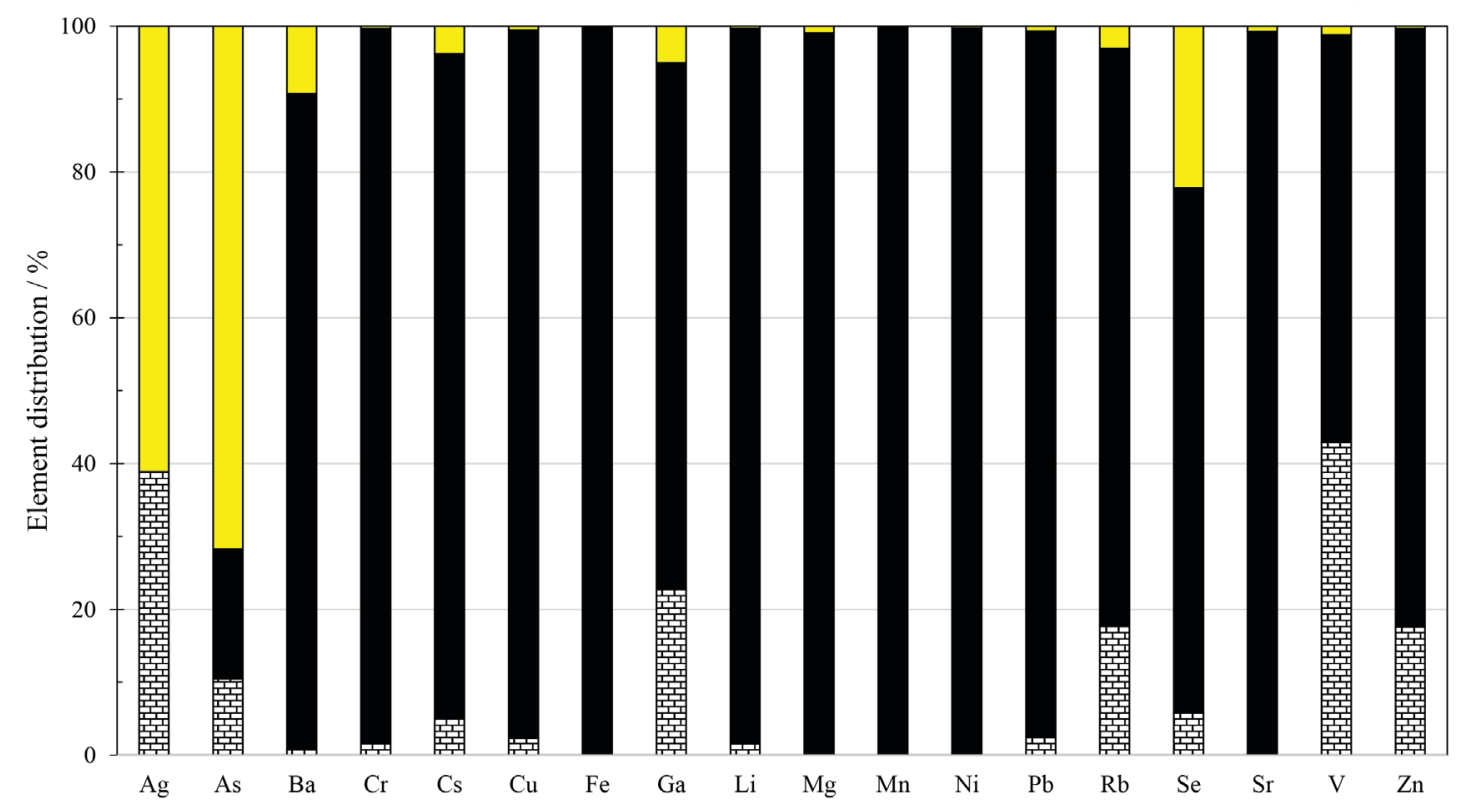

(b)

$\square 4 \mathrm{~A}$

- $\mathrm{NaP} 1$

由Effluent

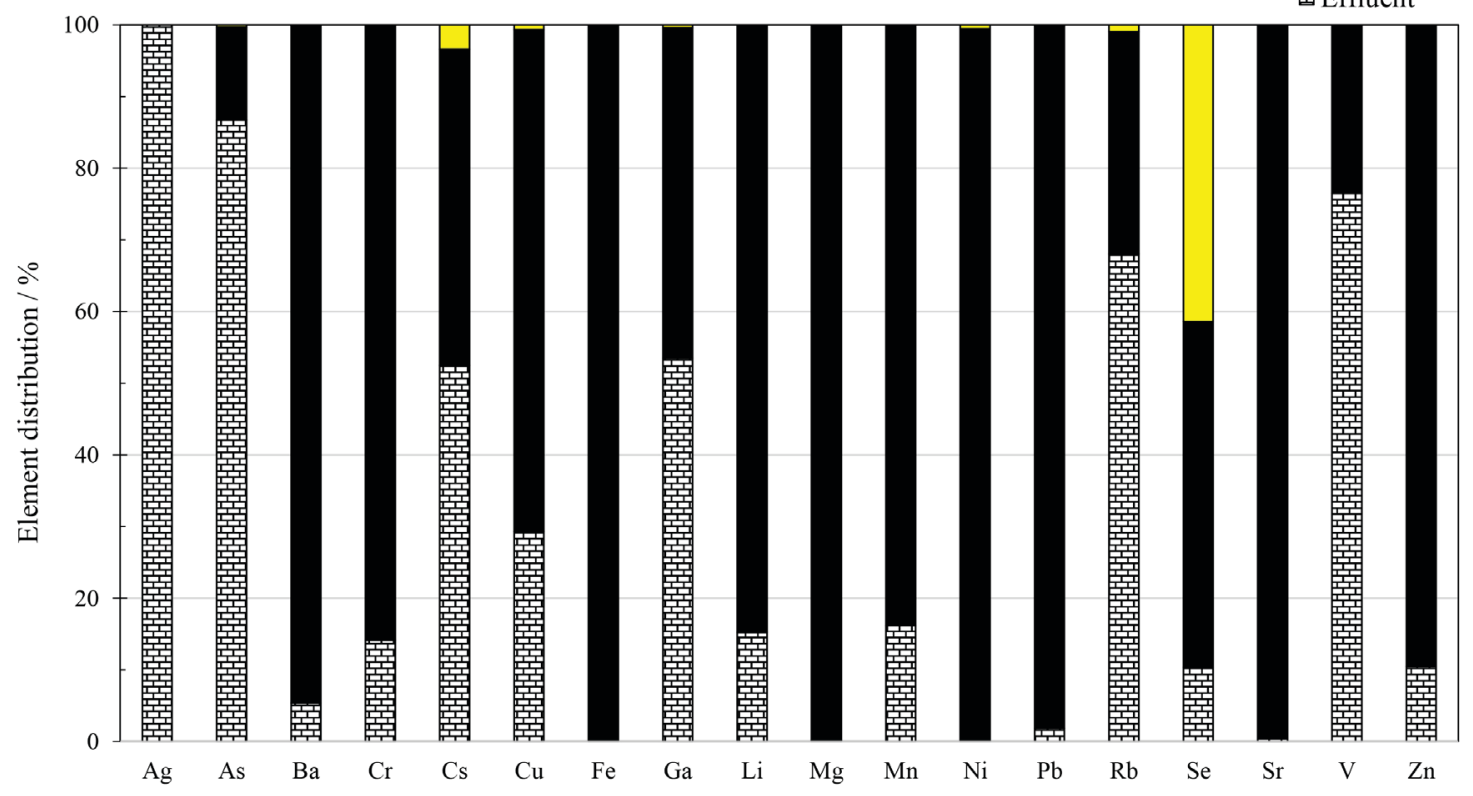

Figure 6. Percentage distribution of elements in the zeolitic products and effluents generated in (a) process A and (b) process B.

The data in Table 6 indicate worse performance for process B (22 $\pm 1 \mathrm{~mL}$ effluent $\mathrm{g}^{-1}$ zeolite), with a value ca. 3 times higher than in process A. These results are partly related to the larger $(2 \times)$ initial $\mathrm{L} / \mathrm{S}$ ratio for process $\mathrm{B}$ compared to process $\mathrm{A}$, as well as better yields in the latter. Moreno et al. ${ }^{33}$ and Hollman et al. ${ }^{18}$ did not report the effluent volume generated in their research; however,
$\mathrm{E}_{\mathrm{Z}}$ was estimated based on the initial solvent volumes, resulting in values between 5 and $6 \mathrm{~mL}$ effluent $\mathrm{g}^{-1}$ zeolite, respectively. These smaller values are partially due to the low $\mathrm{L} / \mathrm{S}$ ratio used by the authors $\left(3 \mathrm{~mL} \mathrm{~g}^{-1}\right)$, which also directly affects yield and consequently, zeolite production. Nevertheless, the lower ratio may undermine extraction performance and/or the quality of the low-grade zeolite. 
Table 6. Characterization, yields, and effluent generation for zeolite Na-P1 and $4 \mathrm{~A}$ synthesis using integrated processes

\begin{tabular}{|c|c|c|c|c|c|c|}
\hline \multirow{2}{*}{ Parameter } & & \multicolumn{2}{|c|}{ Integrated processes (this study) } & \multirow{2}{*}{$\mathrm{A}^{33}$} & \multirow{2}{*}{\multicolumn{2}{|c|}{$\mathrm{B}^{18}$}} \\
\hline & & $\mathrm{A}$ & $\mathrm{B}$ & & & \\
\hline Fly ash & & Candiota UB (Brazil) & Candiota UB (Brazil) & Puertollano (Spain) & \multicolumn{2}{|c|}{ un (Netherlands) } \\
\hline Total mass & $\mathrm{m}_{\mathrm{FA}} / \mathrm{g}$ & $15.023 \pm 0.03$ & $30.001 \pm 0.002$ & 1,000 & \multicolumn{2}{|c|}{500} \\
\hline Silicon & $\mathrm{m}_{\mathrm{Si} F \mathrm{~F}} / \mathrm{g}$ & $4.668 \pm 0.01$ & $9.321 \pm 0.002$ & 274 & \multicolumn{2}{|c|}{220} \\
\hline Aluminum & $\mathrm{m}_{\mathrm{Al} \mathrm{FA}} / \mathrm{g}$ & $1.785 \pm 0.004$ & $3.565 \pm 0.002$ & 145 & \multicolumn{2}{|c|}{132} \\
\hline \multirow[t]{2}{*}{ Solvent } & $\mathrm{NaOH} /\left(\mathrm{mol} \mathrm{L}^{-1}\right)$ & 3 & 2 & 2 & \multicolumn{2}{|c|}{2} \\
\hline & $\mathrm{m}_{\mathrm{Na} \mathrm{Ext}} / \mathrm{g}$ & 6.21 & 13.8 & 138 & & \\
\hline Extract & & & & & & \\
\hline Time & time / h & 24 & 2 & 9 & & \\
\hline Temperature & $\mathrm{T} /{ }^{\circ} \mathrm{C}$ & 100 & 85 & 90 & & \\
\hline Liq/Solid ratio & $\mathrm{L} / \mathrm{S} /\left(\mathrm{mL} \mathrm{g}^{-1}\right)$ & 6.0 & 10.0 & 3 & & \\
\hline Volume & $\mathrm{V}_{\mathrm{Ex}} / \mathrm{mL}$ & $74 \pm 6$ & $258 \pm 3$ & 3,000 & & \\
\hline Concentration & $\mathrm{C}_{\mathrm{si} \text { Ext }} /\left(\mathrm{mL} \mathrm{g}^{-1}\right)$ & $19,493 \pm 2,391$ & $7,235 \pm 330$ & 21,814 & & \\
\hline & $\mathrm{C}_{\mathrm{Al} \text { Ext }} /\left(\mathrm{mL} \mathrm{g}^{-1}\right)$ & $239 \pm 167$ & $531 \pm 11$ & 53 & & \\
\hline Recovery & $\mathrm{Y}_{\mathrm{si} \text { ext }} / \%$ & 31 & 20 & 24 & & \\
\hline & $\mathrm{Y}_{\mathrm{Al} \text { ext }} / \%$ & 1.0 & 4 & 0.1 & & \\
\hline Al source & & powder Al & aluminate & $\mathrm{Al}$ effluent & & \\
\hline $\mathrm{Al}$ added & $\mathrm{m}_{\mathrm{Al} \text { ad }} / \mathrm{g}$ & $1.4 \pm 0.18$ & $3.4 \pm 0.2$ & 63 & & \\
\hline Parameter & & Integrated pro & ses (this study) & $\mathrm{A}^{33}$ & & \\
\hline Parameter & & $\mathrm{A}$ & $\mathrm{B}$ & A & & \\
\hline Zeolite & & Na-P1 & Na-P1 & Na-P1 & $\mathrm{Na}-\mathrm{P} 1$ & $4 \mathrm{~A}$ \\
\hline Mass & $\mathrm{mP} / \mathrm{g}$ & $13.2 \pm 0.4$ & $24.8 \pm 0.3$ & 817 & 515 & 40 \\
\hline & & & & 267 & & \\
\hline & $\mathrm{Y}_{\mathrm{P}} / \%$ & $37 \pm 4$ & $25 . \pm 0.4$ & 87 & & \\
\hline Silicon & $\mathrm{m}_{\text {Si.Z }} / \mathrm{g}$ & $1.8 \pm 0.3 \quad 0.9 \pm 0.2$ & $2.3 \pm 0.2 \quad 0.9 \pm 1.4$ & 63 & 44 & 5 \\
\hline & $\Sigma \mathrm{m}_{\mathrm{Si.Z}} / \mathrm{g}$ & 2.7 & 3.2 & 193 & & \\
\hline & $\mathrm{I}_{\mathrm{Si}} / \%$ & $59 \pm 8$ & $44 \pm 2$ & 54 & & \\
\hline Aluminum & $\mathrm{m}_{\mathrm{Al} . \mathrm{Z}} / \mathrm{g}$ & $0.2 \pm 0.2 \quad 0.9 \pm 0.2$ & $2 \pm 3 \quad 0.82 \pm 0.04$ & 61 & 25 & 5 \\
\hline & $\Sigma \mathrm{m}_{\mathrm{Al} . \mathrm{Z}} / \mathrm{g}$ & 1.9 & 2.7 & 135 & & \\
\hline & $\mathrm{I}_{\mathrm{Al}} / \%$ & $60 \pm 2$ & $39 \pm 1$ & 53 & & \\
\hline CEC & $\mathrm{Ca}^{2+} /($ meq L L $)$ & $4.8 \pm 0.5$ & $4.3 \pm 1.6$ & 5 & & 4 \\
\hline & $\mathrm{NH}_{4}^{+} /\left(\right.$meq L $\left.{ }^{-1}\right)$ & $3.0 \pm 0.6$ & $2.8 \pm 0.1$ & & & \\
\hline Effluent & $\mathrm{V}_{\mathrm{Ef}} / \mathrm{mL}$ & $113 \pm 9$ & $447 \pm 5$ & 4,020 & & \\
\hline Ratio effluent/zeolite & $\mathrm{R}_{\mathrm{Ef} . \mathrm{Z}} /\left(\mathrm{mL} \mathrm{g}^{-1}\right)$ & $8 \pm 1$ & $22 \pm 1$ & 5 & & \\
\hline $\begin{array}{l}\text { UB: unit } \mathrm{B} \text { of the Pres } \\
\text { ash; } \mathrm{m}_{\mathrm{Na} \text { Exx }}: \text { Na mass } \mathrm{i} \\
\text { extracted; } \mathrm{m}_{\mathrm{Al}}: \text { alum } \\
\sum_{\mathrm{mAl.}}: \text { combined mass } \\
\mathrm{V}_{\mathrm{Ef}} \text { : effluent volume; } \\
\text { SI section, under the } \mathrm{i}\end{array}$ & $\begin{array}{l}\text { dente Médici Therm } \\
\text { a the extract; } \mathrm{V}_{\mathrm{Ex}} \text { : ex } \\
\text { num mass added; } \mathrm{m} \\
\text { of the } \mathrm{Si} \text { and } \mathrm{Al} \text { in tl } \\
\text { Ef.Z: effluent/zeolite } \\
\text { em "Calculation of }\end{array}$ & $\begin{array}{l}\text { oelectric Power plant }(\mathrm{Ca} \\
\text { tract volume; } \mathrm{C}_{\mathrm{Si} \text { Ext }} \text { and } \mathrm{C} \\
\mathrm{P} \text { : mass of the product; } \mathrm{Y}_{\mathrm{I}} \\
\text { he zeolites; } \mathrm{I}_{\mathrm{Si}} \text { and } \mathrm{I}_{\mathrm{Al}} \text { : per } \\
\text { ratio; un: uninformed. An } \\
\text { teolitic product purity". }\end{array}$ & $\begin{array}{l}\text { ta, Brazil); } \mathrm{m}_{\mathrm{FA}} \text { : initial ast } \\
\text { e concentration of } \mathrm{Si} \text { and } \\
\text { tage of } \mathrm{Si} \text { and } \mathrm{Al} \text { incorpor } \\
\text { lanation on how the calcu }\end{array}$ & $\begin{array}{l}\mathrm{ss} ; \mathrm{m}_{\mathrm{Si} \mathrm{FA}} \text { and } \mathrm{mAl}_{\mathrm{FA}}: \text { ir } \\
\text { the extract; } \mathrm{Y}_{\mathrm{Si} \text { Ext }} \text { and } \\
\text { and } \mathrm{mAl}_{\mathrm{Z}}: \mathrm{Si} \text { and } \mathrm{Al} \text { 1 } \\
\text { into both zeolites; } \mathrm{CE} \\
\mathrm{ns} \text { in this table were } \mathrm{p}\end{array}$ & $\begin{array}{l}\text { mass o } \\
\text { Ext: perc } \\
\text { in the } \\
\text { ation ex } \\
\text { rmed car }\end{array}$ & $\begin{array}{l}\mathrm{d} \mathrm{Al} \text { i } \\
\mathrm{Si} \text { an } \\
\sum_{\mathrm{mSi}} \\
\text { capa }\end{array}$ \\
\hline
\end{tabular}

As such, it is important to find a compromise between these two L/S ratios.

As previously mentioned, effluents of both the processes studied exhibited similar residual concentrations for the three component elements ( $\mathrm{Si}, \mathrm{Al}$ and $\mathrm{Na}$ ). Low $\mathrm{Al}$ and particularly Si values indicate good use of these elements in synthesis, whereas high $\mathrm{Na}$ levels suggest reuse of the effluent in a new cycle of synthesis. It is important to underscore that the alkaline reagent used in synthesis extracts a series of contaminants (items "Characterization of the effluents generated in the two processes" and "Zeolite contamination between the two synthesis processes") and the selection of the most suitable synthesis process should be based on the intended application of the synthetic zeolites. This finding indicates the need for a more detailed analysis of other factors associated with the two synthesis methods, such as the quality of the products generated, in order to determine which of the two methods offers the best cost-effectiveness as a function of a specific application.

\section{Conclusions}

The present study analyzed two integrated hydrothermal synthesis process (A and B) conducted in two steps 
(extraction and synthesis), producing two types of high (4A) and medium-purity (Na-P1) zeolites and using coal fly ash as the main feedstock. With respect to the reproducibility of extraction, relatively low coefficients of variation were recorded for $\mathrm{Si}$ and greater variability for $\mathrm{Al}$, indicating that analytical uncertainties contributed to the determination of this element due to the low associated concentrations.

While both processes produced zeolite Na-P1 with similar morphology and purity (61 and 65\%), the purity of zeolite $4 \mathrm{~A}(83 \%)$ generated by process A was significantly higher. Nevertheless, contaminant levels were similar in the analogous zeolites in both processes. Exceptions were evident for $\mathrm{Ba}, \mathrm{Mg}$ and Se in zeolite $4 \mathrm{~A}$, exhibiting differences 20 times greater between the two synthesis processes. For zeolites Na-P1 obtained by both processes, $65 \%$ of the elements studied exhibited equal concentrations $(p=0.05)$. Of the elements not included in this percentage, most displayed higher concentrations in the zeolite obtained using process $\mathrm{A}$.

In relation to the effluent generated in both processes, high $\mathrm{Na}$ levels were observed in association with the alkaline reagent used, demonstrating its possible reuse in an additional synthesis process. The exceptionally low $\mathrm{Si}$ content recorded in both processes suggests good atom efficiency for this element. Concentrations of most of the elements investigated were higher in process $\mathrm{B}$. The permissible limit for wastewater discharge was exceeded for $\mathrm{Al}, \mathrm{V}, \mathrm{As}, \mathrm{Ag}$ and $\mathrm{Cr}$ in one or other of the two processes used.

The results for parameters related to process efficiency and sustainability show greater and better extraction $(31 \%$ recovery) in relation to $\mathrm{Si}$ for process $\mathrm{A}$. With respect to $\mathrm{Al}$, low efficiency values were recorded in both processes, indicating inferior mobility when compared to Si. Process A generated a higher mass of products in relation to the amount of ash used and greater purity for both zeolites. It is important to note that this parameter does not adequately portray the reaction yield because additional feedstocks $(\mathrm{NaOH}$ and secondary $\mathrm{Al}$ source) were used and added to the final product. With respect to use of the $\mathrm{Si}$ and $\mathrm{Al}$ available in the feedstocks and incorporated into the zeolites, in process $\mathrm{A}, 60 \%$ of the available $\mathrm{Si}$ and $\mathrm{Al}$ was incorporated into the two produced zeolites, while lower incorporation $(44 \%$ of $\mathrm{Si}$ and $39 \% \mathrm{Al})$ was observed in process B. In general, yields demonstrated better performance in process A for both zeolites assessed, in line with the behavior of the other parameters studied. In terms of effluent generation and its treatability / recyclability, performance was worse in process $\mathrm{B}$.

It should be noted that both synthesis processes produced zeolites of sufficient quality for application in the removal of metals from wastewater (zeolite Na-P1) and in detergents as builder (zeolite 4A). For applications subject to more stringent requirements (biopolymer composites / biodegradable packaging), additional tests (leaching tests) should be performed to ensure safe use of these zeolites. Larger scale testing and economic assessment of the integrated synthesis processes are currently underway in order to better ascertain their cost-effectiveness in terms of a specific application.

\section{Supplementary Information}

Supplementary information (data, figures, list of symbols, etc.) is available free of charge at http://jbcs.sbq.org.br.

\section{Acknowledgments}

This work was supported by Conselho Nacional de Desenvolvimento Científico e Tecnológico (CNPq) (grant number 490218/2012-1). M. J. R. Pires is grateful to CNPq for the Research Productivity (PQ) (grant number 312323/2015-8). A. M. Cardoso thanks the Coordenação de Aperfeiçoamento de Pessoal de Nível Superior (CAPES) for the $\mathrm{PhD}$ and Sandwich PhD scholarships (grant number 249526/2013-1), and S. F. Ferrarini is grateful to CAPES/ FAPERGS (Fundação de Amparo à Pesquisa do Estado do Rio Grande do Sul) for the postdoctoral fellowship (grant number 2843-25.51/12-3).

\section{References}

1. Aldahri, T.; Behin, J.; Kazemian, H.; Rohani, S.; Fuel 2016, $182,494$.

2. Blissett, R. S.; Rowson, N. A.; Fuel 2012, 97, 1.

3. Kalhreuth, W.; Levandowski, J.; Int. J. Coal Geol. 2009, 77, 269.

4. Lopez-Anton, M. A.; Fernández-Miranda, N.; Martínez-Tarazona, M. R.; Environ. Sci. Pollut. Res. 2016, 23, 24495.

5. Ferrarini, S. F.; Cardoso, A. M.; Paprocki, A.; Pires, M. J.; J. Braz. Chem. Soc. 2016, 27, 2034.

6. Cardoso, A. M.; Paprocki, A.; Ferret, L. S.; Azevedo, C. M. N.; Pires, M.; Fuel 2015, 139, 59.

7. Wang, J.; Li, D.; Ju, F.; Han, L.; Chang, L.; Bao, W.; Fuel Process. Technol. 2015, 136, 96.

8. Gonzalez, A.; Navia, R.; Moreno, N.; Waste Manage. Res. 2009 , $27,976$.

9. Monzón, J. D.; Pereyra, A. M.; Conconi, M. S.; Basaldela, E. I.; J. Environ. Chem. Eng. 2017, 5, 1548.

10. Schwanke, A. J.; Pergher, S. B. C.; Probst, L. F. D.; Balzer, R.; J. Braz. Chem. Soc. 2017, 28, 42. 
11. Vicente, J. G. P.; Lima, P. M.; Cardoso, D.; Catal. Lett. 2017, 147, 880.

12. Bukhari, S. S.; Behin, J.; Kazemian, H.; Rohani, S.; Fuel 2015 , 140, 250.

13. Cardoso, A. M.; Horn, M. B.; Paprocki, A.; Ferret, L. S.; Azevedo, C. M. N.; Pires, M.; J. Hazard. Mater. 2015, 287, 69.

14. Behin, J.; Bukhari, S. S.; Dehnavi, V.; Kazemian, H.; Rohani, S.; Chem. Eng. Technol. 2014, 37, 1532.

15. Belviso, C.; Cavalcante, F.; Huertas, F. J.; Lettino, A.; Ragone, P.; Fiore, S.; Microporous Mesoporous Mater. 2012, 162, 115.

16. Holler, H.; Wirsching, U.; Fortschr. Mineral. 1985, 63, 21.

17. Musyoka, N. M.; Petrik, L. F.; Balfour, G.; Gitari, W. M.; Hums, E.; J. Environ. Sci. Health, Part A: Toxic/Hazard. Subst. Environ. Eng. 2011, 46, 1699.

18. Hollman, G. G.; Steenbruggen, G.; Janssen-Jurkovicova, M. A.; Fuel 1999, 78, 1225.

19. Querol, X.; Moreno, N.; Umaña, J. C.; Alastuey, A.; Hernández, E.; López-Soler, A.; Plana, F.; Int. J. Coal Geol. 2002, 50, 413.

20. Lee, Y.-R.; Soe, J. T.; Zhang, S.; Ahn, J.-W.; Park, M. B.; Ahn, W.-S.; Chem. Eng. J. 2017, 317, 821.

21. Mallapur, V. P.; Oubagaranadin, J. U. K.; Trans. Indian Ceram. Soc. 2017, 76, 1.

22. Menezes, R. A.; Paz, S. P. A.; Angélica, R. S.; Neves, R. F.; Neumann, R.; Faulstich, F. R. L.; Pergher, S. B. C.; Clay Miner. 2017, 52, 83.

23. Vinaches, P.; Alves, J. A. B. L. R.; Melo, D. M. A.; Pergher, S. B. C.; Mater. Lett. 2016, 178, 217.

24. Verboekend, D.; Perez-Ramírez, J.; ChemSusChem 2014, 7, 753.

25. Meng, X.; Feng-Shou, X.; Chem. Rev. 2014, 114, 1521.

26. Martinez, C.; Corma, A.; Coord. Chem. Rev. 2011, 255, 1558.

27. Zeng, S.; Wang, R.; Zou, Y.; Fu, J.; Zhang, Z.; Qiu, S.; RSC Adv. 2015, 5, 95463.

28. Behin, J.; Bukhari, S. S.; Kazemian, H.; Rohani, S.; Fuel 2016, $171,195$.

29. Hui, K. S.; Chao, C. Y. H.; J. Hazard. Mater. 2006, 137, 401.

30. Depoi, F. S.; Pozebon, D.; Kalkreuth, W. D.; Int. J. Coal Geol. 2008, 76, 227.

31. Pires, M.; Querol, X.; Int. J. Coal Geol. 2004, 60, 57.

32. ASTM D1426-08: Standard Test Methods for Ammonia Nitrogen in Water, United States, 2008.

33. Moreno, N.; Querol, X.; Plana, F.; Andres, J. M.; Janssen, M.; Nugteren, H.; J. Chem. Technol. Biotechnol. 2002, 77, 274.

34. Moreno, N.; Querol, X.; Lopez-Soler, A.; Andres, J. M.; Janssen, M. H. M.; Nugteren, H.; Stanton, K.; J. Chem. Technol. Biotechnol. 2004, 79, 1009.

35. Anastas, P. T.; Eghbali, N.; Chem. Soc. Rev. 2010, 39, 301.

36. Baird, C.; Cann, M.; Química Ambiental, 4ª ed.; Bookman: Porto Alegre, Brasil, 2011.

37. National Environmental Council (CONAMA); Resolução No. 430/2011 Dispõe Sobre Condições e Padrões de Lançamento de Efluentes, Complementa e Altera a Resolução No. 357, de 17 de março de 2005, Publicação Diário Oficial da União No. 92, de 16 de maio de 2011, p. 89.

38. Industrias Químicas del Ebro, S.A. IQESIL y DESILSA (Grupo IQE); Metodos Analíticos de Control de Qualidad: Determinación De LaAlcalinidad Libre Em Zeolita 4A - PT5/A2; IQE: Zaragoça, Spain, 2004.

39. Querol, X.; Moreno, N.; Alastuey, A.; Juan, R.; Andrés, J. M.; López-Soler, A.; Ayora, C.; Medinaceli, A.; Valero, A.; Geol. Acta 2007, 5, 49.

40. Franus, W.; Wdowin, M.; Franus, M.; Environ. Monit. Assess. 2014, 186, 5721.

41. Sánchez-Hernández, R.; López-Delgado, A.; Padilla, I.; Galindo, R.; López-Andrés, S.; Microporous Mesoporous Mater. 2016, 226, 267.

42. Bieseki, L.; Penha, F. G.; Pergher, S. B. C.; Mater. Res. (Sao Carlos, Braz.) 2013, 16, 38.

43. Mainganye, D.; Ojumu, T. V.; Petrik, L.; Materials 2013, 6, 2074.

44. Belviso, C.; Cavalcante, F.; Di Gennaro, S.; Palma, A.; Ragone, P.; Fiore, S.; Fuel 2015, 144, 369.

45. Izidoro, J. C.; Fungaro, D. A.; dos Santos, F. S.; Wang, S.; Fuel Process. Technol. 2012, 97, 38.

46. Izquierdo, M.; Querol, X.; Int. J. Coal Geol. 2012, 94, 54.

47. Dudas, M. J.; Environ. Sci. Technol. 1981, 15, 840.

48. Fruchter, J. S.; Rai, D.; Zachara, J. M.; Environ. Sci. Technol. 1990, 24, 1173.

49. Kim, A. G.; Kazonich, G.; Dahlberg, M.; Environ. Sci. Technol. 2003, 37, 4507.

50. Cornelis, G.; Johnson, C. A.; Gerven, T. V.; Vandecasteele, C.; Appl. Geochem. 2008, 23, 955.

51. Querol, X.; Umaña, J. C.; Alastuey, A.; Ayora, C.; Lopez-Soler, A.; Plana, F.; Fuel 2001, 80, 801.

52. Fungaro, D. A.; Izidoro, J. C.; Quim. Nova 2006, 29, 735.

53. Wasem, A.; Bôer, S. C.; Sabedot, S.; da Cunha, A. C. B.; Matéria (Rio J.) 2015, 20, 193.

54. State Environmental Council (CONSEMA); Resolução No. 128/2006 Dispõe sobre a Fixação de Padrões de Emissão de Efluentes Líquidos para Fontes de Emissão que Lancem seus Efluentes em Águas Superficiais no Estado do Rio Grande do Sul, de 24 de novembro de 2006, Diário Ofical do Estado, 2006.

55. Dufour, J.; González, V.; La Iglesia, A.; Ind. Eng. Chem. Res. 2001, 40, 1140.

56. Miller, J. N.; Miller, J. C.; Statistics and Chemometrics for Analytical Chemistry, $6^{\text {th }}$ ed.; Pearson: England, 2010.

57. Auerbach, S. M.; Carrado, K. A.; Dutta, P. K.; Handbook of Zeolite Science and Technology; Marcel Dekker, Inc.: New York, USA, 2003, p. 585.

Submitted: September 28, 2017

Published online: February 6, 2018 